\title{
LOWER AND MIDDLE CAMBRIAN BRACHIOPODS FROM THE IBERIAN CHAINS AND SIERRA MORENA (SPAIN)
}

\author{
Eladio LIÑÁN' and Michal MERGL ${ }^{2}$ \\ ' Departamento de Ciencias de la Tierra. (Paleontología). \\ Universidad de Zaragoza. 50009-Zaragoza (España). \\ ? Katedra biologie, Pedagogická Fakulta, Západočeská \\ Univerzita, Klatovská 51, PLZEŇ 30619 (Czech Republic).
}

\begin{abstract}
Liñán, E. and Mergl, M. 2001. Lower and Middle Cambrian brachiopods from the Iberian Chains and Sierra Morena (Spain). [Braquiópodos del Cámbrico Inferior y Medio de las Cadenas Ibéricas y de Sierra Morena (España).] Revista Española de Paleontología, 16(2), 317-337. ISSN 0213-6937.
\end{abstract}

\begin{abstract}
Brachiopods from the Lower and Middle Cambrian of the Iberian Chains and Sierra Morena are described. The following taxa occur in the Iberian Chains: "Lingulella" sp., Redlichella cf. bohemica (Barrande), Dictyonina radioplicata sp. n., Micromitra sp., Trematobolus simplex (Vogel), Trematobolus borobiensis sp. n. and Jamesella sp. The taxa "Lingulella " sp. and Sibiria? sp. are reported from the Lower Cambrian of Sierra Morena. Brachiopods constitute several distinct associations: the relatively shallow water Trematobolus assemblage near the Lower-Middle Cambrian boundary interval is followed by the deeper DictyoninaRedlichella assemblage. The alternation of these assemblages permit us to interpret the response of brachiopod communities to sea level changes.
\end{abstract}

Keywords: Brachiopoda, Lower Cambrian, Middle Cambrian, Spain.

\section{RESUMEN}

Se revisan los braquiópodos del Cámbrico Inferior y Medio de las Cadenas Ibéricas y de Sierra Morena. En las Cadenas Ibéricas están presentes los siguientes taxones: "Lingulella" sp., Redlichila cf. bohemica (Barrande), Dyctionina radiplicata sp. n., Micromitra sp., Trematobolus simplex (Vogel), Trematobolus borobiensis sp. n. y Jamesella sp., mientras que "Lingulella" sp. y Sibiria? sp. se citan en el Cámbrico Inferior de Ossa-Morena. Se reconocen dos asociaciones de braquiópodos: la asociación de Trematobolus, que es típica de aguas someras, y la asociación de Dictyonina-Redlichella, que es típica de aguas más profundas. Ello permite interpretar la alternancia de asociaciones como una respuesta de las comunidades de braquiópodos a los cambios del nivel del mar acaecidos.

Palabras clave: Brachiopoda, Cámbrico Inferior, Cámbrico Medio, España.

\section{INTRODUCTION}

The Cambrian System in Spain is one of the most widespread of Europe and contains a diversified fossil record where the brachiopods are present fiom Lower to Upper Cambrian rocks.

The objective of this work is to revise from a taxonomic and palaeoecological point of view the inarticulate brachiopod assemblages from selected Lower-Middle Cambrian sections in Sierra Morena and the Iberian Chains.

In Sierra Morena (Fig. 1), we study brachiopods from two localities: the Arroyo Tamujar and Río Viar, all of them in the Capas de Benalija Formation, sensu Lotze
(1961). The palaeontological site named Arroyo Tamujar is located in the crossing between the Tamujar stream with the Guadalcanal-Cazalla road. Fossils from Río Viar are located in the crossing between the Viar river and the Llerena-Pallarés road. Both localities have the same trilobite assemblage. It is represented by Andalusiana sp., Aldonaia sp. and Termierella sp. suggesting a Middle Marianian age (mid Lower Cambrian).

In the Iberian Chains (Fig. 2), the studied brachiopods are from Jarque 1 section (Liñán et al., 1996a), Mesones 3 section (Valenzuela et al., 1990), Rambla de Valdemiedes 1-4 sections in Murero locality (Liñán and Gozalo, 1986, Gozalo et al., 1996) and Villafeliche 1 section (Gozalo et al., 1993, 1996) and Borobia 1 section 


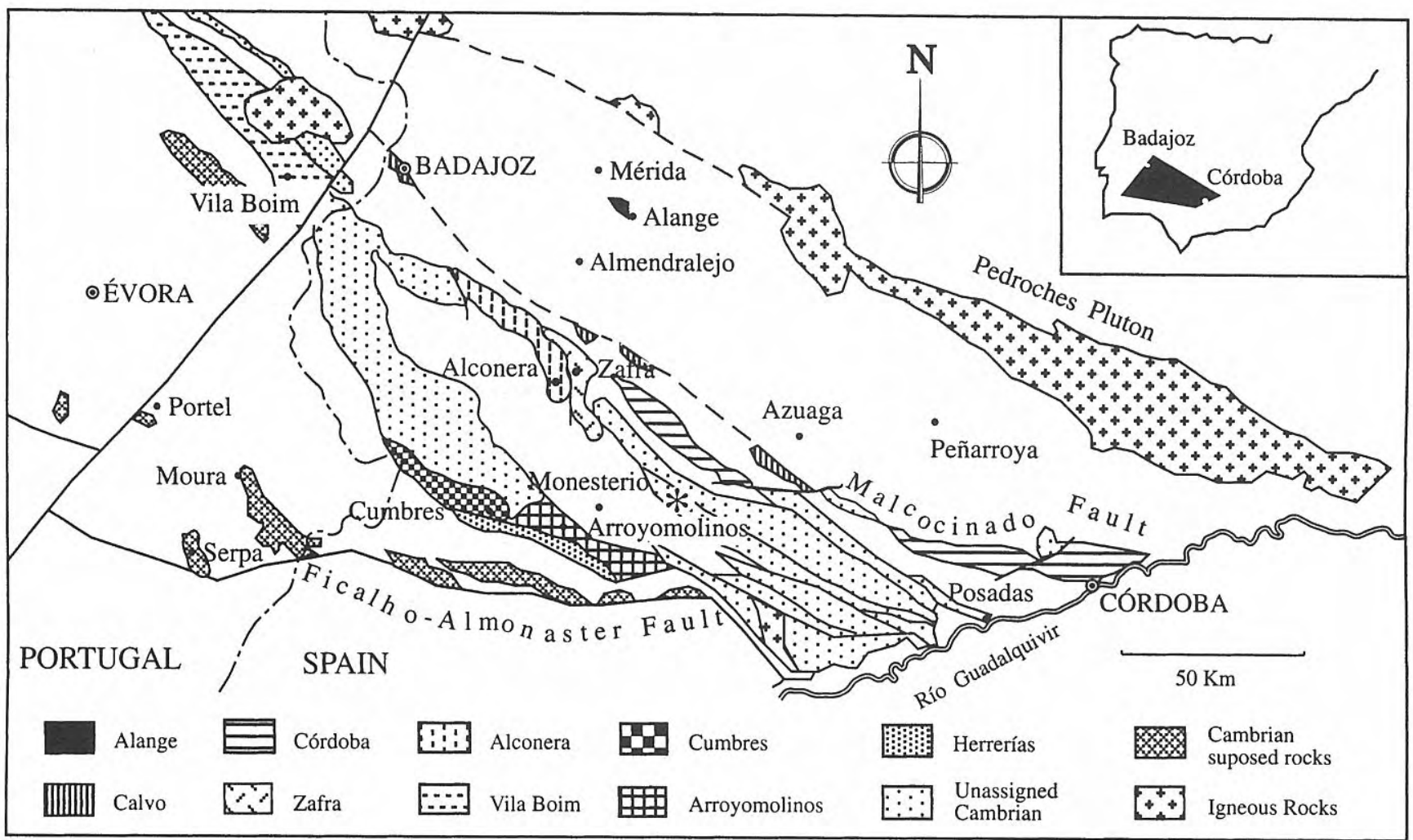

Figure 1. Geological map of Sierra Morena showing the fault-bounded troughs proposed by Liñán and Quesada (1990) with the location of the nearest Río El Viar and Arroyo Tamujar brachiopods localities mentioned in the text (*).

(Gámez et al., 1991). The associated trilobites permit us to have a good chronostratigraphical control of the brachiopoda occurrence from the Bilbilian (Lower Cambrian) to Caesaraugustan (Middle Cambrian) rocks of the Iberian Chains. Finally, the study of a precise stratigraphical distribution of brachiopoda will provide us with a better environmental knowledge of the brachiopoda asemblages through the ecological facies analysis sugested by Liñán (1995).

From a chronostratigraphical point of view, we will use here the Spanish Stages nomenclature sensu Liñán et al. (1993a) to present the stratigraphical distribution of the studied taxa (Fig. 3).

\section{PREVIOUS WORK}

Brachiopods from the Cambrian rocks of the Iberian Chains were probably observed in Murero by Palacios (1893) and Dereims (1898) where they cited but did not figure Leperditia sp. and Discina sp., respectively. Sampelayo (1935) figured, although he did not described, probably the first brachiopoda from Murero as Fordilla marini which is considered herein a nomen nudum. Brachiopods from Murero have been described by Vogel (1962) who interpreted the presence of the obolellid Trematobolus Matthew as a bivalve. Havlíček and Kř́íz (1978) re-evaluated the systematic position of the supposed bivalve Lamellodonta simplex Vogel and assigned this species to the brachiopod genus Trematobolus. Other detailed studies of the brachiopods from Iberian Chains and Sierra de la Demanda can be found in Mergl and Liñán (1986), and a short note on
Mediterranean Trematobolus species which is present in Geyer and Mergl (1995). Cambrian brachiopods from Sierra Morena have been studied by Liñán and Mergl (1983) who found Paterina sp., Acrothele sp. and Obolella sp. in Lower Cambrian rocks (Ovetian and Marianian) and by Gil Cid and Melou (1988) who found the new species Yorkia zafrensis and Jamesella iberica in Middle Cambrian rocks (Caesaraugustan).

\section{STRATIGRAPHY}

In the Iberian Chains, the Lower-Middle Cambrian sequence overlie the proterozoic Paracuellos Group (Lotze, 1961) and it is composed of the Bámbola, Embid, Jalón, Ribota, Huérmeda, Daroca, Mesones, Valdemiedes, Mansilla, Murero and Borobia formations. The brachiopods studied here are from Huérmeda to Murero formations.

The Ribota Formation (Lotze, 1929) is a 25 to $130 \mathrm{~m}$ thick succession composed of yellow and grey dolostones, minor limestones and interbedded shales and marls containing trilobites, brachiopods, echinoderms, hyoliths and trace fossils. Gámez et al. (1991) cited oncolites, cryptalgal and stromatolitic laminations and gypsum pseudomorphs in dolostones from the lower part of this formation. Two successive trilobite assemblages are recorded in the shales; the lower is characterised by Lusatiops ribotanus Richter and Strenuaeva incondita Sdzuy and the upper contains Kingaspis velatus Sdzuy, Redlichia and Strenuaeva species (Sdzuy, 1971a). The 


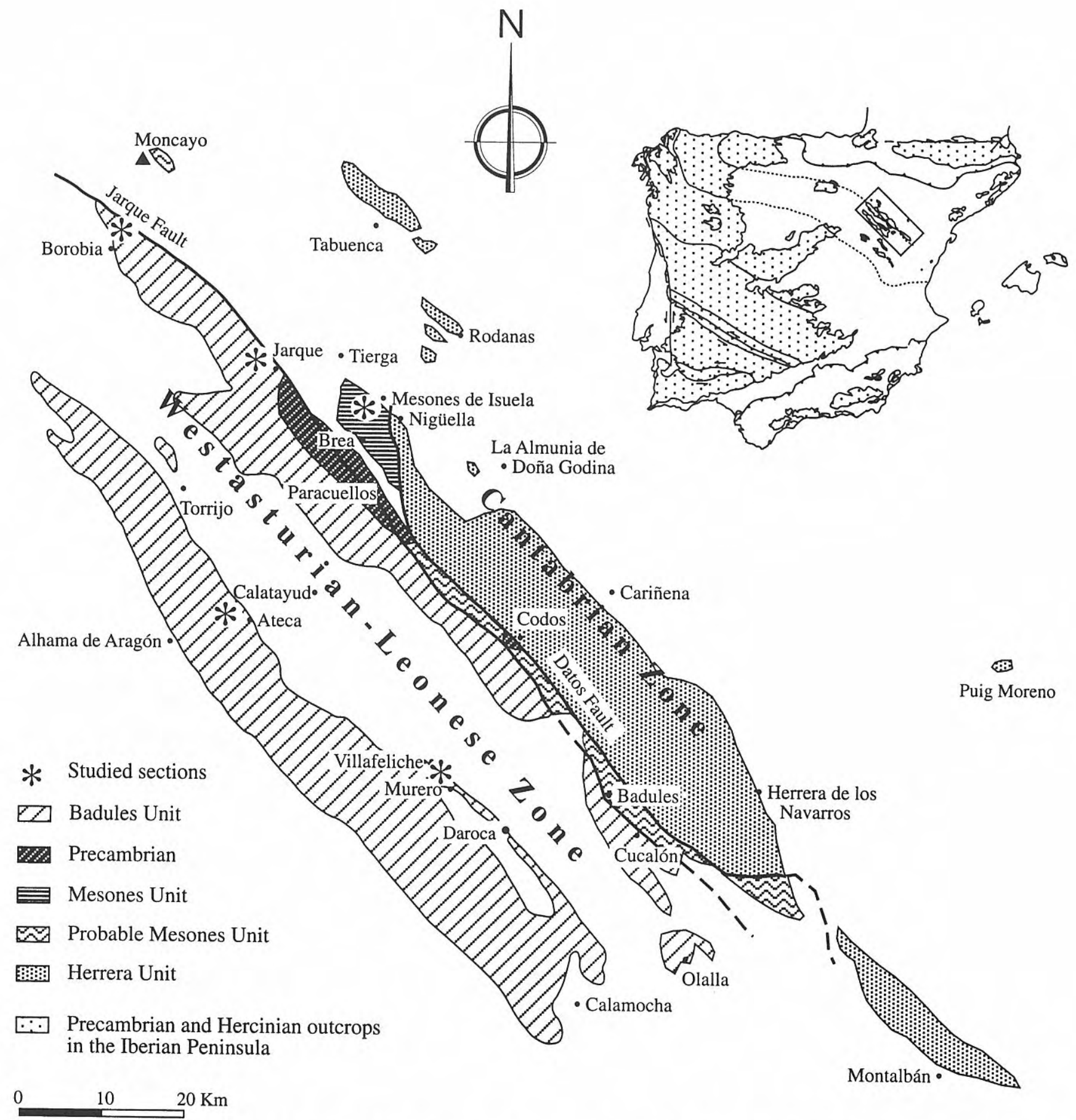

Figure 2. Geological setting of the Iberian Chains (modified after Gozalo and Liñán, 1988). Studied localities (*).

genera Strenuaeva and Lusatiops are typical of the Marianian stage. Acritarchs are also reported from the upper part of this formation (Gámez et al., 1991; Liñán et al., 1996b). This formation was deposited under oscillating littoral to shallow sublittoral conditions (Schmidt-Thomé, 1973; Álvaro et al., 1995). The Ribota Formation is the thickest Cambrian carbonate succession in the Iberian Chains.

The Huérmeda Formation (Lotze, 1929) is 45 to $80 \mathrm{~m}$ thick and comprises green to dark blue shales with yellow dolostones deposited under sublittoral conditions (Álvaro et al., 1995). This unit contains scattered trilobites, brachiopods, echinoderms, hyoliths, acritarchs and ichnofossils. Trilobites are present both at the base and at the top of the Huérmeda Formation. The lower trilobite assemblage with Micmacca, Andalusiana, Strenuaeva, Redlichia and Triangulaspis (Sdzuy, 1961, 1971a) suggests a Marianian age. The upper trilobite assemblage with Strenuaeva sp. and protolenids (Sdzuy, 1971a) documents the dissappearance of the trilobite olenellids in Spain and indicates a Bilbilian age. Recently, acritarch assemblages have been found in the North of the Iberian Chains (Liñán et al., 1996b, Palacios and Mockzylowska, 1998). They confirm a Bilbilian age. 


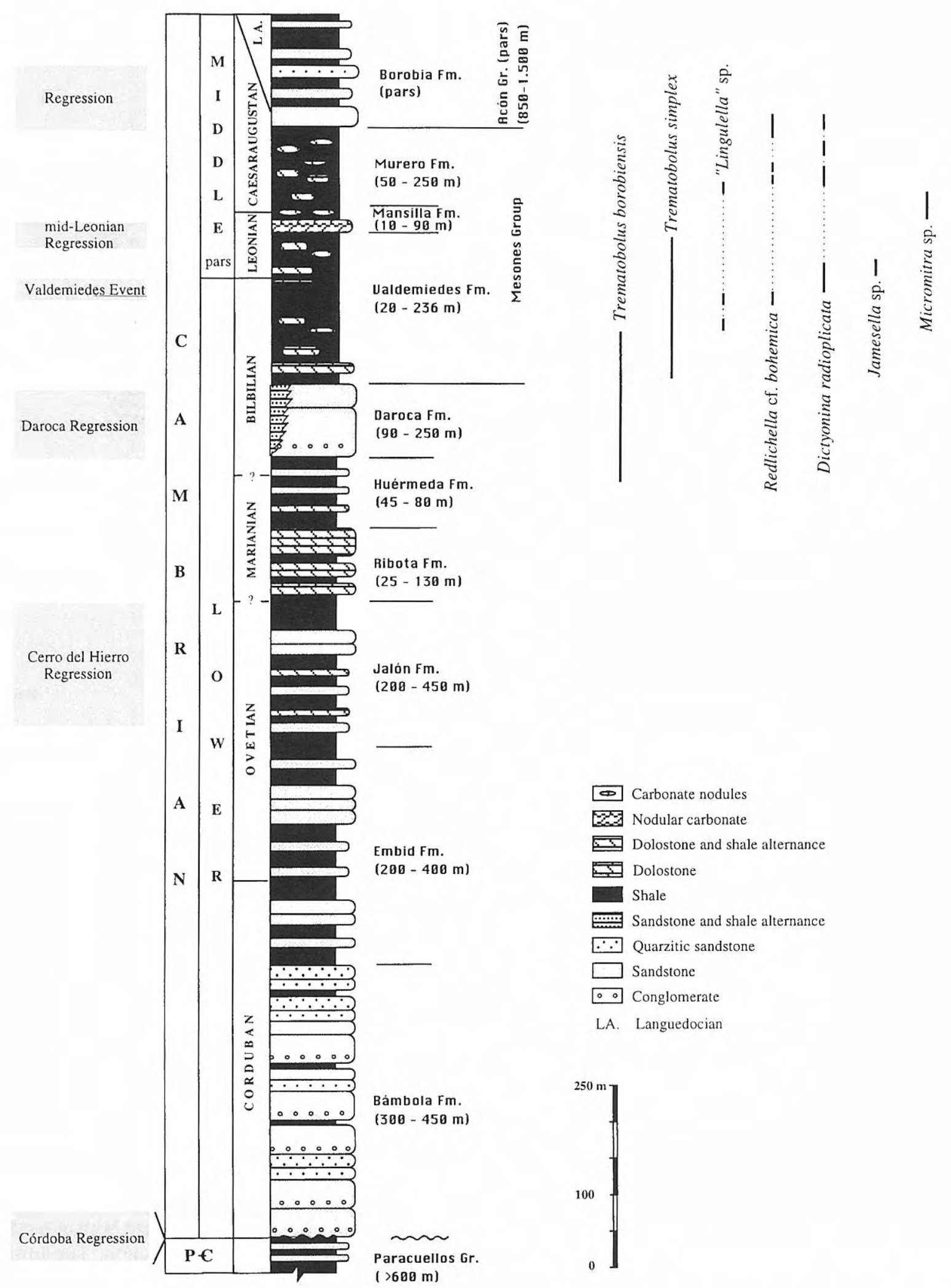

Figure 3. Synthetic Lower-Middle Cambrian stratigraphy (Gozalo, 1995) and brachiopod distribution of the Iberian Chains.

The Daroca Formation (Lotze, 1929) is a terrigenous sequence 90-250 m thick with very heterogeneous lithologies among its outcrops (Sdzuy and Liñán, 1993). All the southern outcrops of the Iberian Chains are mainly composed of sandstones with scarce conglomerates. In the central outcrops, shale forms 60 $75 \%$ of the components, and the amount of sandstone decreases when approaching the northwestern part of the Iberian Chains. In some northern localities, the trilobite Protolenus (Hupeolenus) Geyer has been found in the 
Daroca Formation (Álvaro and Liñán, 1997) together with the acritarch assemblage described previously for the Huérmeda Formation (Liñán et al., 1996b). Thus, a Bilbilian age can also be inferred for the Daroca Formation.

The Mesones Group (Liñán et al., 1992) is subdivided into three formations (Valdemiedes, Mansilla and Murero), and is essentially composed of shales with carbonate nodules, dolostones and limestones interbedded. These materials were mainly deposited in sublittoral environments (Sdzuy and Liñán, 1993).

The Valdemiedes Formation is $20-236 \mathrm{~m}$ thick, and has yielded trilobites, brachiopods, hyoliths, sponges, algae, annelids? and ichnofossils. The trilobite genera can be separated into a lower assemblage with Protolenus (Hupeolenus), Hamatolenus (Hamatolenus), Hamatolenus (Myopsolenus?), Kingaspis, Alueva, Tonkinella, Sdzuyia and Onaraspis (Upper Bilbilian) and an upper assemblage represented by Eoparadoxides, Paradoxides (Eccaparadoxides), Hamatolenus, Alueva, Protolenus (Hupeolenus), Asturiaspis, Peronopsis and Condylopyge (Sdzuy, 1961; Liñán and Gozalo, 1986; Liñán et al., 1993b; Gozalo et al. 1993; Gozalo and Liñán, 1995). This findings suggest a Lower to early Middle Leonian ages. Both assemblages are separated by the Valdemiedes event (Liñán et al., 1993b), which has been interpreted to produce the trilobite turnover at the Lower-Middle Cambrian boundary in Iberia (Sdzuy 1971a, b, 1995; Liñán and Gozalo, 1986, Álvaro et al., 1993b; Gozalo et al., 1993). This event may be the last expression of the uppermost Lower Cambrian mass extinction, which was followed by a trilobite diversification at the early Middle Cambrian.

The Mansilla Formation, 10-90 m thick, is made up of an alternance of brown dolostones and limestones and purple and violet shales containing trilobites, brachiopods, sponges, algae, hyoliths, monoplacophoran and ichnofossils. Trilobites have been found only in the upper part and their assemblages are composed of Paradoxides (Eccaparadoxides) sulcatus Liñán and Gozalo, 1986, Paradoxides (Ecc.) asturianus Sdzuy, 1968, Paradoxides (Ecc.) sdzuyi Liñán, 1978, Cornucoryphe schirmi Sdzuy and Liñán, 1997, Conocoryphe (Parabailiella) sp., Holocephalina? leve Gozalo and Liñán, 1996, Asturiaspis inopinatus Sdzuy, 1968, Acadolenus sp. and Peronopsella prokovskajae Sdzuy, 1968, thus suggesting a late Leonian age (Liñán and Gozalo, 1986; Gámez et al., 1991; Gozalo et al. 1993; Gozalo and Liñán, 1995, 1996; Sdzuy and Liñán, 1997).

The Murero Formation, 50-250 m thick, is composed of green lutites with carbonate nodules interbedded with very fine sandstones. It has yielded trilobites, brachiopods, annelids? (palaeoscolecid worms), algae, hyoliths, sponges and ichnofossils of Caesaraugustan age.

The Acón Group (Acón Formation, Schmitz, 1971) is a succession up to $1,500 \mathrm{~m}$ thick of white and grey sandstones and green shales with isolated carbonate nodules. The Acón Group conformably overlies the regionally diachronous top of the shaly green Murero
Formation (Gámez et al., 1991). Álvaro (1995) subdivided this group into five formations, in ascending order, Borobia, Valdeorea, Torcas, Encomienda and Valtorres formations. This group yields trilobites, brachiopods, echinoderms, acritarchs and ichnofossils of Caesaraugustan to Upper Cambrian.

The Borobia Formation (Álvaro, 1995) consists of alternating sandstones and shales. Minor carbonate nodules are also present. It reaches a maximum thickness of $250 \mathrm{~m}$. Schmitz (1971), Josopait (1972) and Shergold and Sdzuy (1991) recognised three fossil assemblages composed of trilobites, echinoderms and brachiopods: 1) the Ctenocephalus bergeroni assemblage; 2) the Chilidorthis tecta and Bailiella levyi assemblage; and 3) the Bailiella cf. levyi, Conocoryphe ferralsensis, Paradoxides macrocercus, Brahimorthis cf. antiqua and Sucocystis melendezi assemblage across the Borobia/Valdeorea transition. Because of the presence of C. ferralsensis Courtessole and P. macrocercus Courtessole the third assemblage probably correlates with the $\mathrm{H} 1$ palaeontological level of the Montagne Noire (Courtessole et al., 1988).

The stratigraphical distribution of the studied brachiopoda results as follows. The top of Huérmeda Formation and the Daroca Formation has yielded Trematobolus borobiensis sp. n., all specimens from the Borobia locality. The Valdemiedes Formation (latest Early-early Middle Cambrian) contains the brachiopods: Trematobolus cf. borobiensis sp. n., Trematobolus simplex (Voge1), Dictyonina radioplicata $\mathrm{sp} . \mathrm{n}$., Redlichella cf. bohemica (Barrande), "Lingulella" sp. and Jamesella sp. Since Trematobolus simplex, Dictyonina radioplicata and Redlichella cf. bohemica are all included in Lower and Middle Cambrian strata, it could be considered that brachiopoda are not affected by the Lower-Middle Cambrian extintion, although the Valdemiedes event produced a decrease in the size of the specimens and some changes in the structure of the brachiopod communities. The Mansilla Formation has yielded the brachiopods: Micromitra sp., Trematobolus simplex (Vogel), Dictyonina radioplicata $\mathrm{sp}$. $\mathrm{n}$. and Redlichella cf. bohemica (Barrande). Finally, the Murero Formation contains Micromitra sp., "Lingulella" sp., Dictyonina radioplicata sp. $\mathrm{n}$. and Redlichella cf. bohemica (Barrande).

The specimens from Sierra Morena are from Lower Cambrian rocks of Sevilla Province where Fricke (1941) distinguished as being in a stratigraphical order: the Estebayanes Beds, the Agua Limestone and the Benalija Beds (Lotze, 1961; Liñán and Mergl, 1983). The last unit contains the brachiopod Sibiria? sp. which is now studied.

\section{BRACHIOPOD ASSEMBLAGES}

The data about the brachiopod palaeobiogeography and benthic communities of the Early and Middle Cambrian ages are poor, when compared with the data about benthic communities of younger ages. This is 
caused by a dominance of the lingulates and other less studied groups of brachiopods (paterinids, obollelids) among the fossil records, while the rhynchonellate ("articulate") brachiopods are generally less common. Quantitative and distributional information on these faunas is generally missing in published data.

The brachiopod species derived from the Lower and Middle Cambrian of the Iberian Chains belongs to two distinct brachiopod assemblages. These assemblages can be respectively included inside the calcareous and phosphatic brachiopod biofacies, defined by Liñán et al. (1993b).

The Trematobolus assemblage is characterized by a total prevalence of the large, thick-walled and calcareousshelled Trematobolus. This genus possesses a dorsibiconvex shell and a large pedicle opening protruded by a wholly functional pedicle.

Taphonomy of the valves, that often form densely packed clusters (especially in the Borobia section) as well as associated fossils, indicate a shallow sublittoral environment affected by a wave and current activity, as was previously suggested by Gámez et al. (1991), Sdzuy and Liñán (1993), Gámez Vintaned and Mayoral Alfaro (1992), Liñán et al. (1993b) and Álvaro et al. (1993a). The abundant occurrence of Trematobolus around the Lower-Middle Cambrian boundary (the Huérmeda, Daroca, Valdemiedes and Murero formations) coincides with an increase of the supply of detritic material (Daroca Regression and Valdemiedes event; Liñán et al. 1993b, Álvaro et al. 1993b).

Despite the different, mainly volcanoclastic development, the similar environment and habitat are indicated by the taphonomy of the Trematobolus-bearing beds in Morocco. Their valves are also thick walled, being densely and randomly packed together, often crushed and abraded. There the sediments were also deposited under a shallow subtidal environment (Geyer and Mergl, 1995).

The Dictyonina-Redlichella assemblage is the second distinct brachiopod assemblage in the Iberian Chains. The Dictyonina-Redlichella assemblage is characterized by a prevalence of small, phosphatic-shelled brachiopods which belong mainly to genera Dictyonina Cooper and Redlichella Walcott. Minute obolid-like brachiopods are very scarce and they are represented only by minute forms. Commonly bivalved, rarely fragmental shells indicate a quiet, deeper basinal environment as is also suggested by the trilobite assemblages. Some preserved shell clusters may even represent the original live, abruptly buried associations. Genera Dictyonina, Redlichella, as well as Micromitra in the lower part of the
Middle Cambrian sequence, belong to the epibenthic brachiopods. The functional pedicle penetrated the ventral apex in the acrothelid Redlichella, while the pedicle protruded between the homoeodeltidium and the homoechilidium in the paterinid genera.

The absence of minute obolids in the associations with abundant paterinids is also reported by Rowell (1980) from Nevada. Rarity of lingulellids in associations with acrothelids is also known in other places with Middle Cambrian sequences in Europe (Termier and Termier, 1974; Mergl and Šlehoferová, 1990).

\section{BRACHIOPOD ASSEMBLAGES OF MIDDLE CAMBRIAN IN SOUTHWESTERN AND CENTRAL EUROPE, AND NORTH AFRICA}

Although our present knowledge of the benthic brachiopod faunas of the Early to Middle Cambrian ages in Western and Central Europe and Northern Africa is not sufficient, some general conclusions may be inferred from the available data.

The Spanish brachiopod assemblages are quite different from the Middle Cambrian brachiopod assemblages of the Central Bohemia. The latter ones are mainly dominated by large obolids (genera Westonia, Lindinella and Lingulella), which dwelled in shallow and sandy bottom environments. In Bohemia, the deeper, basinward Acrothele assemblage is characterized by the scarce occurrence of Redlichella and Acrothele, rare minute lingulellids, the fairly abundant acrotretid brachiopod Vandalotreta and the locally numerous orthid Bohemiella (Havlíček, 1971; Mergl and Šlehoferová, 1990). However, the paterinids and Trematobolus are usually absent in Central Bohemia. The absence of Trematobolus may only reflect an inappropriate environment, because the oldest marine trilobite-bearing fauna (Fatka et al., 1992) in the lowermost part of the Jince Formation in Bohemia is surely lower than the upper stratigraphical range of Trematobolus in Spain (Mergl and Liñán, 1986).

Brachiopod assemblages of Montagne Noire are little known, but common occurrence of acrothelids (Acrothele, Redlichella) indicates the presence of the Acrothele assemblage and deeper conditions in Middle Cambrian rocks in this area. Unlike Bohemia, the paterinid brachiopods are present but poorly described from that area (Termier and Termier, 1974).

Moroccan late Early Cambrian to early Middle Cambrian transition is characterized, as concerning the

Figure 4. a-h. Redlichella cf. bohemica (Barrande). a. ventral and dorsal valves, internal mould, MPZ97/476, x5. b. ventral valve, latex cast of exterior, MPZ97/477, x5. c. dorsal valve, composite mould, MPZ97/478, x5. d. dorsal valve interior, MPZ97/479, x5. e, f. two dorsal valves, internal moulds partly with original shell, and detail of pustulose ornamentation, MPZ97/480, x8, x15. g. ventral valve, external mould, MPZ97/481, x5. h. ventral valve, internal mould, MPZ97/482, x8. i-k. Sibiria (?) sp. i. ventral valve, internal mould, MPZ97/554, x10. j. dorsal valve, internal mould, MPZ97/555, x10. k. ventral valve, external mould, MPZ97/556, x10. 1. "Lingulella” sp. ventral valve interior, MPZ97/483, x8. 

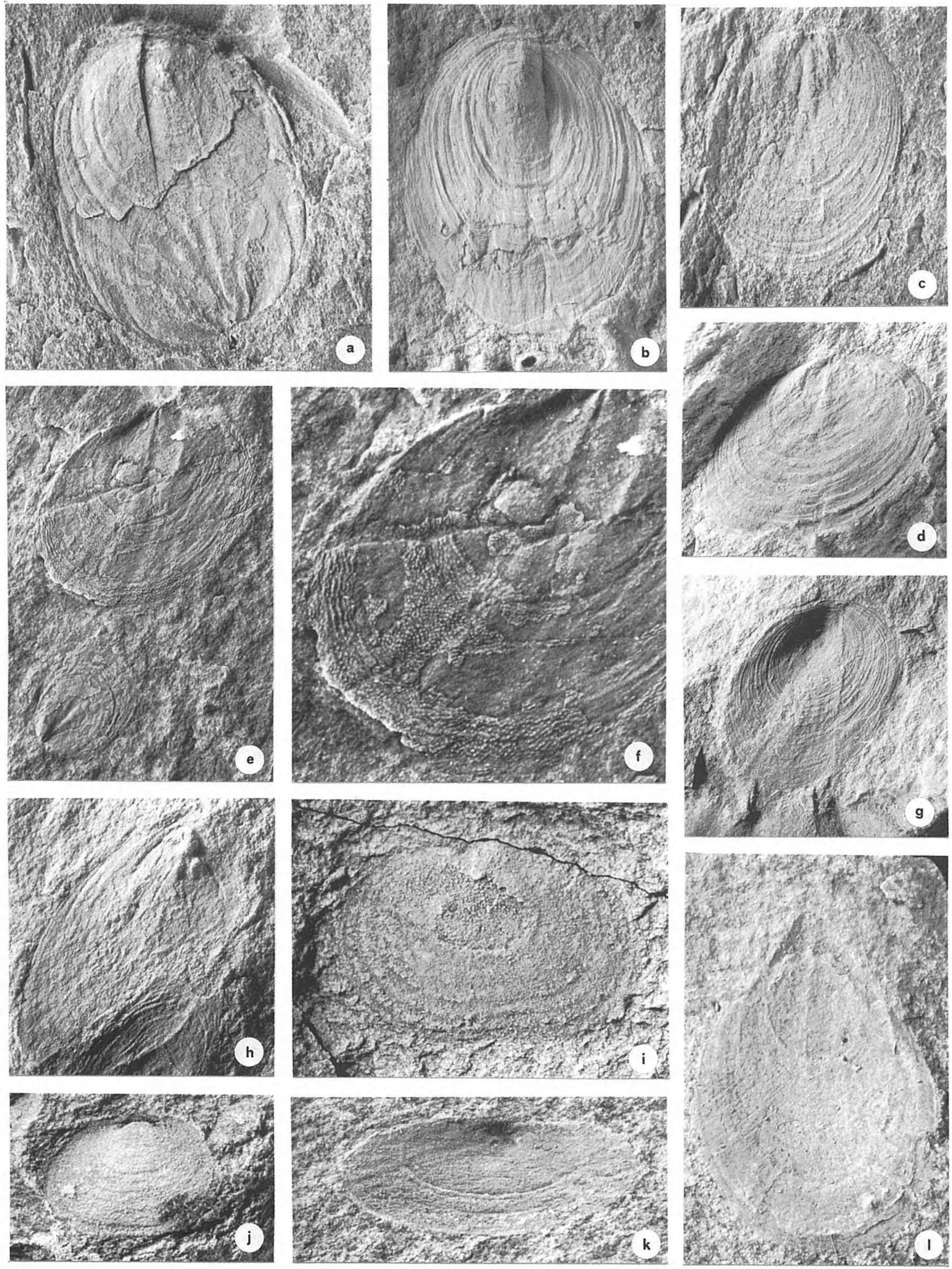
brachiopods, by a local dominance of Trematobolus (Geyer and Mergl, 1995). The typical deeper Acrothele assemblage is not reported from the area, although some of its elements, such as minute lingulellids, the acrotretid Valdalotreta, and Botsfordia are known from a few localities (Mergl, 1988). Diverse ceratretids, recently described from the basal Middle Cambrian of Morocco (Streng, 1997) have been unknown in Spain up to now. Locally numerous orthid brachiopods near the base of the Middle Cambrian rocks in Morocco (Havlíček, 1971; Geyer and Mergl, in prep.) occurr only rarely in the Iberian Chains.

\section{SYSTEMATIC}

If not stated otherwise, the material used in the study is deposited in the Museo Paleontológico de la Universidad de Zaragoza (DPZ 176, 179; MPZ96/500-1032; MPZ97/454505), Spain. Descriptive terminology follows Rowell (1965).

CLASS LINGULATA Gorjansky and Popov, 1985

ORDER LINGULIDA Waagen, 1885

Superfamily Linguloidea Menke, 1828

Family Obolidae King, 1846

Subfamily Obolinae King, 1846

Genus Lingulella Salter, 1866

Type species: Lingula davisii M’Coy, 1851.

$$
\text { "Lingulella" sp. }
$$

Fig. 41

Material: Five specimens. MPZ96/1029-1032; MPZ97/483.

\section{Remarks}

A few poorly preserved small valves of lingulellid appearance are present in the collection. Valves are 4-6 $\mathrm{mm}$ long with a prominent, acuminate beak. They differ from all lingulellids known from the Middle Cambrian of Bohemia (Mergl and S̆lehoferová, 1990) but are similar to minute lingulellids from Morocco (Mergl, 1988) and Montagne Noire, France (Termier and Termier, 1974). A similar shape with an acuminate beak also has the lingulate genus Eoobolus Matthew, recently re-defined by Holmer et al. (1996), but fine morphological details are unknown in the Spanish specimens.

\section{Occurrence}

Sporadic levels in Lower and Middle Cambrian. In the Ossa-Morena zone it is from the Capas de Benalija Formation (mid Marianian, Arroyo Tamujar locality). In the Iberian Chains it is present in the Valdemiedes and Murero Formations (Upper Bilbilian and Caesaraugustan; Rambla de Valdemiedes 1, Jarque 1 and Mesones localities).

Superfamily Acrotheloidea Walcott and Scuchert, 1908

Family Acrothelidae Walcott and Schuchert, 1908

Subfamily Acrothelinae Walcott and Schuchert, 1908 Genus Redlichella Walcott, 1908
(Synonymy: Glyptacrothele Termier and Termier, 1974).

Type species: Acrotreta granulata Linnarsson, 1876.

\section{Discussion}

As noted by Mergl and S̆lehoferová (1990), the species Acrotreta granulata, assigned by Termier and Termier (1974) to Glyptacrothele, is the type species of Redlichella Walcott. We follow here the opinion, that the genus Glyptacrothele Termier and Termier, with the type species Glyptacrothele courtessolei Termier and Termier, is a subjective synonym to the genus Redlichella Walcott. Holmer and Popov (2000) included Redlichella as a synonym of Acrothele but we prefer to stand by the genus Redlichella, at the moment, for morphological and ecological criteria.

\section{Redlichella cf. bohemica (Barrande, 1879) Fig. 4a-h}

1986 Acrothele cf. coriacea Linnarsson, 1876; Mergl and Liñán, p. 169, pl. 3, figs. 14-17.

Material: One hundred fifty specimens, mostly deformed. MPZ96/700-839; MPZ97/476-482.

\section{Description}

Shell large, $9 \mathrm{~mm}$ wide, thin-walled. Ventral valve almost subcircular, some 90 percent similar in length to width, with the apex situated $1.5-1.8 \mathrm{~mm}$ anteriorly to the posterior margin, at about 20 percent of the valve length. Lateral and anterior margins evenly curved, posterior margin adjacent to the pseudointerarea less curved and weakly deflexed ventrally. Anterior margin rectimarginate. Lateral profile with an erect umbo, anterior slope straight in small valves, slighly concave in large specimens. Posterior slope steep, feebly convex in a lateral profile. Ventral pseudointerarea narrowly triangular, at posterior margin equal to 20 percent of the valve width, with obscure interridge. Pedicle foramen circular, located at the top of the apex, fairly large.

Dorsal valve flat, with marginal beak located in weakly ventrally deflexed posterior margin. Thus, the transverse profile of posterior margin of the valve is gently concave. Anterior and lateral margins evenly curved.

Interior of ventral valve with a large, apically situated circular internal pedicle foramen, encircled by a weak pad. Muscle scars poorly defined, only a pair of minute, deeply impressed scars are located immediately anterior to internal pedicle foramen. A fine median ridge extends between the scars and dissappears at the valve midlength. Vascula lateralia poorly impressed, with short, rather narrow, slightly curved, widely divergent canals.

Interior of dorsal valve with a broad and weak median ridge notable along one third of the valve length.

Ornamentation of numerous concentric rugellae of uneven size, more notable along the periphery of the large valves. Some rugellae are coarser, corresponding to an interruption of the growth. The shell surface covered by 
densely packed knob-shaped pustules forming irregular, wave rows. A midsector of the ventral valve bears 4 to 10 weak radial plications, extending from the apex and evenly widening anteriorly. The ventral pseudointerarea bears fine growth lines, abruptly curved at the borders of pseudointerarea. Another inflection of growth lines is notable on a convex surface of the interridge.

\section{Comparison}

All available specimens are similar to species Redlichella granulata (Linnarson) from the Middle Cambrian of Scandinavia (Linnarsson, 1876; Walcott, 1912) as well to Redlichella bohemica (Barrande) from the Middle Cambrian of Central Bohemia. Bohemian specimens display high variabilty in ornamentation, ranging from a prominent concentric ornamentation to a dominant pustulose ornamentation (Mergl and Šlehoferová, 1990). The high variability of the ornamentation is also distinct in the specimens from Spain. The Spanish species seems to be closer to the species Redlichella bohemica; the ventral valves of the former have well developed radial plications and the general shape of the shell is the same. The differences between the Bohemian and Spanish ones are weak but distinct: (1) Well developed ventral interridge in the Spanish specimens which is obscure in Redlichella bohemica, (2) less ventrally deflected posterior margin of Redlichella bohemica, (3) more anteriorly located pair of apical scars, and (4) narrower pallial markings in the Spanish specimens.

The radial plications in the median sector and prominent concentric rugellae of the Spanish specimens are similar to the ornamentation pattern of Acrothele quadrilineata Pompeckj from the Middle Cambrian of Bohemia (Mergl and S̆lehoferová, 1990), but the latter differs by having a more anteriorly located ventral apex, flat interridge and rectimarginate posterior margin.

Mergl and Liñán (1986) referred some unfavourable preserved acrothelids to the species Acrothele coriacea Linnarsson, but the new, more numerous material indicates their closer affinity to the genus Redlichella Walcott. Acrothele coriacea differs by having a poorly developed interridge, more anteriorly located ventral apex and rectimarginate posterior margin. We prefer an open taxonomic position of the Spanish specimens; it is based on unfavourable preservation of our material and a great deal of related but poorly known species in the European Middle Cambrian (Linnarsson, 1876; Walcott, 1912; Cobbold, 1921; Termier and Termier, 1974). This does not exclude the possibility that our specimens belong to Acrothele primaeva (Verneuil and Barrande) from the Cantabrian Mountains, León Province, Spain (Verneuil and Barrande, 1860; Walcott, 1912), but this species needs careful revision.

\section{Occurrence}

Lower-Middle Cambrian (Upper BilbilianCaesaraugustan). The Valdemiedes, Mansilla and Murero formations. Jarque, Mesones, Villafeliche and Murero localities. Abundant in the Murero Formation.

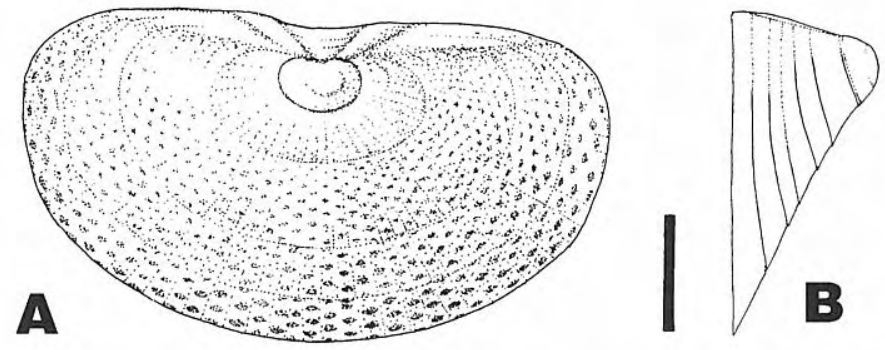

Figure 5. Dictyonina radioplicata $\mathrm{sp}$. n. Reconstruction of exterior of ventral valve $(\mathrm{A})$ and lateral profile of the ventral valve (B). Bar equal to $1 \mathrm{~mm}$.

\author{
CLASS PATERINATA Williams, Carlson, Brunton, \\ Holmer and Popov, 1996 \\ ORDER PATERINIDA Rowell, 1965 \\ Superfamily Paterinoidea Schuchert, 1893 \\ Family Paterinidae Schuchert, 1893
}

Genus Dictyonina Cooper, 1942

Type species: Trematis pannulus White, 1874.

\section{Dictyonina radioplicata $\mathrm{sp} . \mathrm{n}$. Fig. 5, Fig. 6a-m}

1986 Micromitra sp.; Mergl and Liñán, p. 171, pl. 3, fig. 113.

Derivatio nominis: Allusive to the characteristic ornamentation.

Holotype: Ventral valve figured on Fig. 6e,f, deposited in the collections of the Museo Paleontológico de la Universidad de Zaragoza, Spain (MPZ97/463).

Paratype: Dorsal valve figured on Fig. 6g, deposited in the collections of the Museo Paleontológico de la Universidad de Zaragoza, Spain (MPZ97/464).

Type horizon: Middle Cambrian, Caesaraugustan Stage, the Murero Formation.

Type locality: Iberian Chains, Mesones section 1, level 3.

Material: Two hundred specimens, mostly deformed. MPZ96/840-1028; MPZ97/461-469.

Diagnosis: Species of Dictyonina characterized by a large homoeodeltidium which almost entirely covers the delthyrium, a transverse outline of the shell, coarse concentric ornamentation and distinct radial plications.

\section{Description}

Shell ventribiconvex, small, 5.0-5.5 $\mathrm{mm}$ wide in the largest specimens, shell wall rather thick.

Ventral valve semicircular in outline, strongly convex, 
with the apex highly raised above the posterior margin. The valve 60-80 percent similar in length to width, with maximum width posterior to midlength. Posterior margin straight, with procline, widely triangular pseudointerarea. Large delthyrium broadly triangular, almost completely covered by a large, gently convex homoeodeltidium. Cardinal extremities obtuse. Transverse profile of the valve highly convex, lateral profile with a steeply sloping anterior slope, becoming slightly concave near the front margin of the large valves. No fold or sulcus.

Dorsal valve semicircular, weakly convex in transverse profile as well as in lateral profile. Posterior margin straight, lateral margin strongly curved, front margin gently and evenly curved. Apex prominent, with well defined larval shell. Dorsal pseudointerarea low, catacline, bisected by a broad, low notothyrium, covered by a minute homoeochilidium in its apical part.

Concentric ornamentation of distinct growth fila. Radial ornamentation of weak plications in median sector of both valves, 16-20 in number, which are absent on the flanks. Less deformed specimens show shallow transverse pits arranged in oblique rows, increasing in size anteriorly (Fig. $6 \mathrm{e}, \mathrm{f}, \mathrm{m})$. The surface of the homoeodeltidium bears fine transverse growth lines.

Interior of ventral valve with prominent, stout ridges internally bordering the delthyrium. A pair of broadly divergent ridges extend from the umbonal cavity to reach about one third of the valve length. No muscle scars preserved. Dorsal valve interior with fine radial ridges extending anteriorly from the notothyrial cavity.

\section{Remarks}

As noted by Zell and Rowell (1988), systematic relations among the paterinids are an intricate problem. The Spanish species is placed in Dictyonina Cooper, although its probably rather thick-shell, large homoeodeltidium and exterior with strong concentric fila indicate similarity to the new species to Micromitra Meek. The dorsal valve is remarkably similar to the species Micromitra cf. modesta (Lochman) for having a distinctly bordered larval shell of to the dorsal valve (Zell and Rowell, 1988). The type species Micromitra sculptilis (Meek) differs from the new species by a more prominent radial ornamentation and an absence of oblique rows of pits.

The new species is rather similar to Dictyonina pannula (White) from the Lower-Middle Cambrian transitional beds of Nevada. As noted by Rowell (1980), Dictyonina pannula is rather variable in the ornamentation, a feature which is also notable in the Spanish species. However, the Spanish species has more transverse outline of the shell, more coarse concentric ornamentation and distinct radial plications. The large homoeodeltidium almost entirely covers the delthyrium in the new species while the homoeodeltidium of $D$. pannula (White) is minute and restricted only to the top of the delthyrium.

A flattening, deformation and a substitution of the original shell substance by green mineral (chlorite) resulted in absence of the microornamentation in the majority of the available specimens. As noted above, the better preserved specimens display the finely pitted external surface of Dictyonina-like type but the remaining specimens show only concentric lines, often overpronounced due to tectonic deformation. Sometimes, it is difficult to determine whether specimens without pitting are only less favorably preserved valves of the same species, or shells of different but near species. However, the general morphology of all shells is the same; thus, we have selected the valve bearing the pitted superficial ornamentation as the type specimen.

\section{Occurrence}

Lower-Middle Cambrian (Bilbilian, Upper Leonian and Caesaraugustan Stages). Not found in times between the Valdemiedes event and mid Leonian regression. Valdemiedes, Mansilla and Murero formations from Borobia, Mesones, Jarque and Murero localities.

\section{Genus Micromitra Meek, 1873}

Type species: Iphidea sculptilis Meek, 1873

\section{Micromitra sp.}

Fig. 6n-s

Material: Two ventral valves, 8 dorsal valves. PZ97/470475 .

\section{Description}

Shell ventribiconvex, small to medium sized, the largest known valves are $5.5 \mathrm{~mm}$ wide. Shell moderate to thick walled.

Ventral valve little known, transversely oval, about 70 percent similar in length to width, the maximum width at midlength. Apex highly raised above the posterior margin, homoeodeltidium present but little known. Valve surface evenly sloping anteriorly and laterally toward regularly

Figure 6. a-m. Dictyonina radioplicata sp. n. a-c. ventral valve, latex cast, posterior (b) and side views (c), MPZ97/461, x10. d. ventral valve exterior and dorsal valve interior of the same specimen, latex cast, MPZ97/462, x10. e, f. ventral valve exterior, holotype, and posterior (f) views, MPZ97/463, x10. g. dorsal valve exterior, paratype, MPZ97/464, x10. h, i. ventral valve with remnant of original shell, and posterior (i) views, MPZ97/465, x10. j. ventral valve, composite mould, MPZ97/466, x10. k. dorsal valve, exterior, MPZ97/467, x10. l. dorsal valve, exterior, MPZ97/468, x10. m - dorsal valve, exterior with distinct radial plications and oblique rows of superficial pits, MPZ97/469, x10. n-s. Micromitra sp. n. dorsal valve exterior, latex cast, MPZ97/470, x10. o. dorsal valve with original shell, MPZ97/471, x10. p. ventral valve, exterior, MPZ97/472, x10. q. dorsal valve, exterior, MPZ97/473, x10. r. dorsal valve, exterior, latex cast, MPZ97/474, x10. s. dorsal valve, exterior, MPZ97/475, x10. 

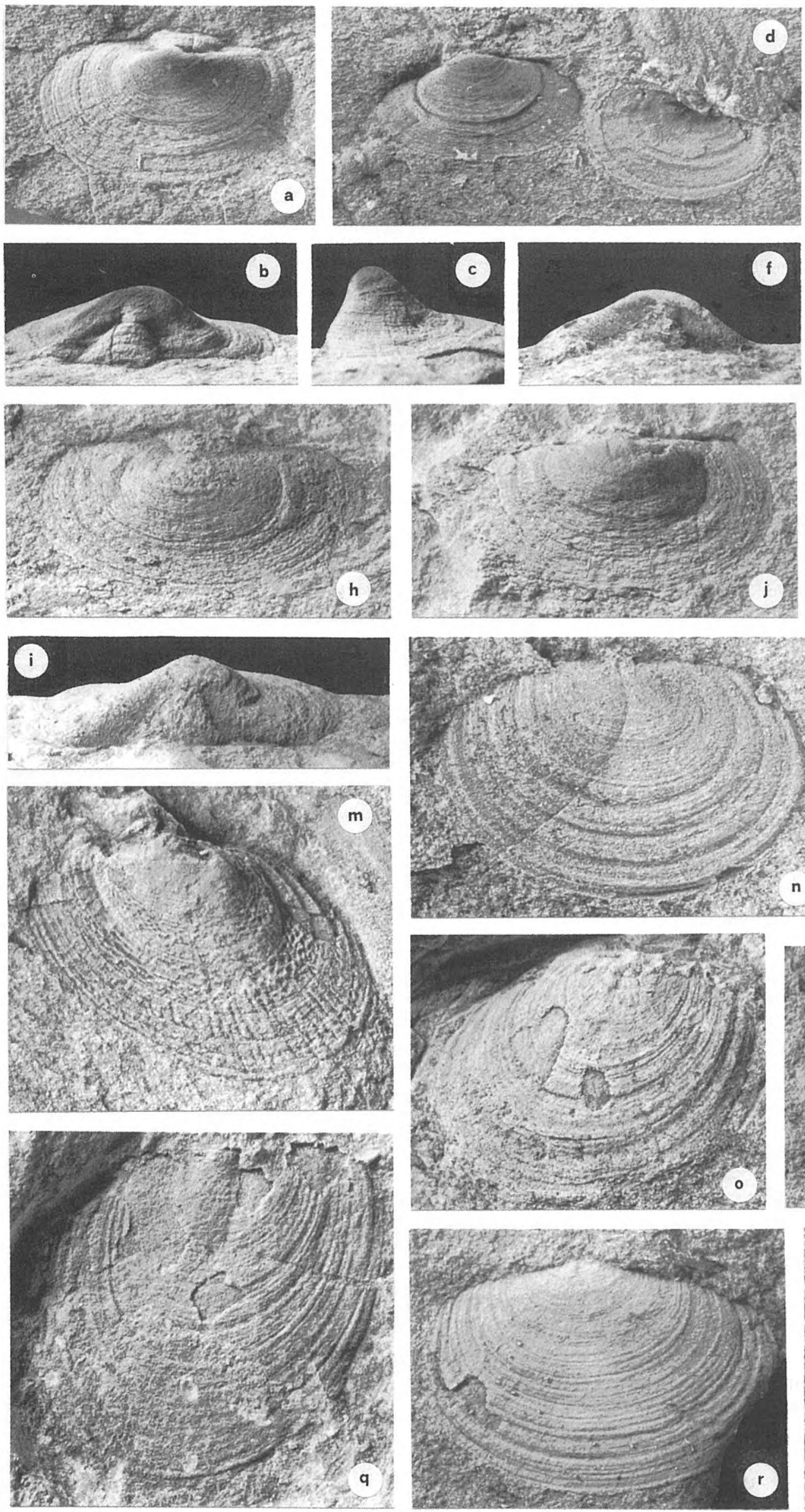
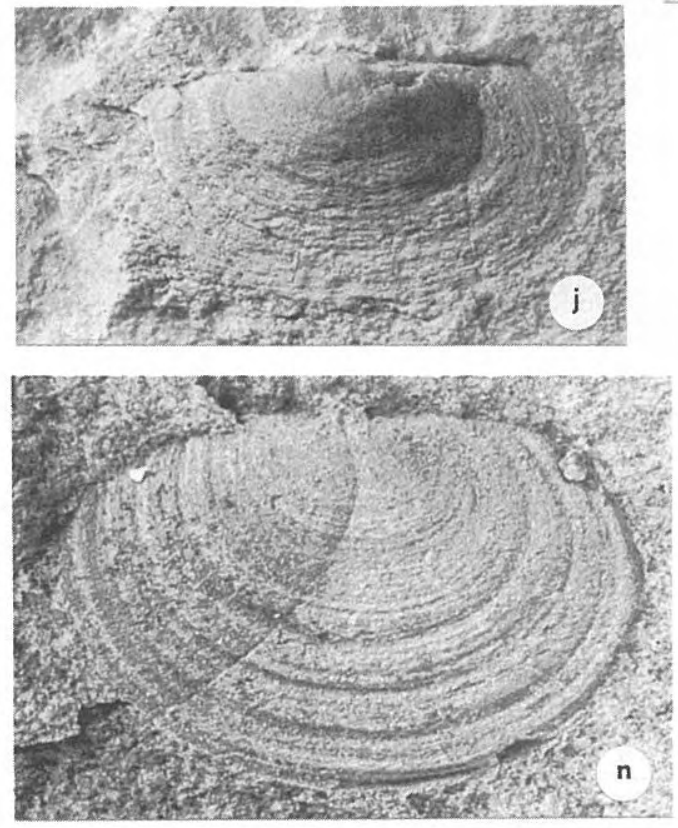
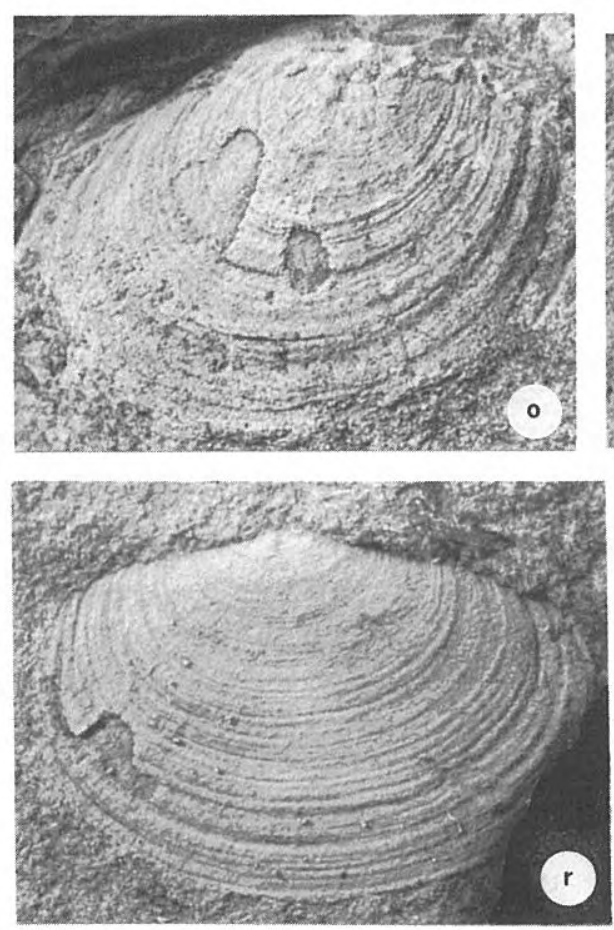
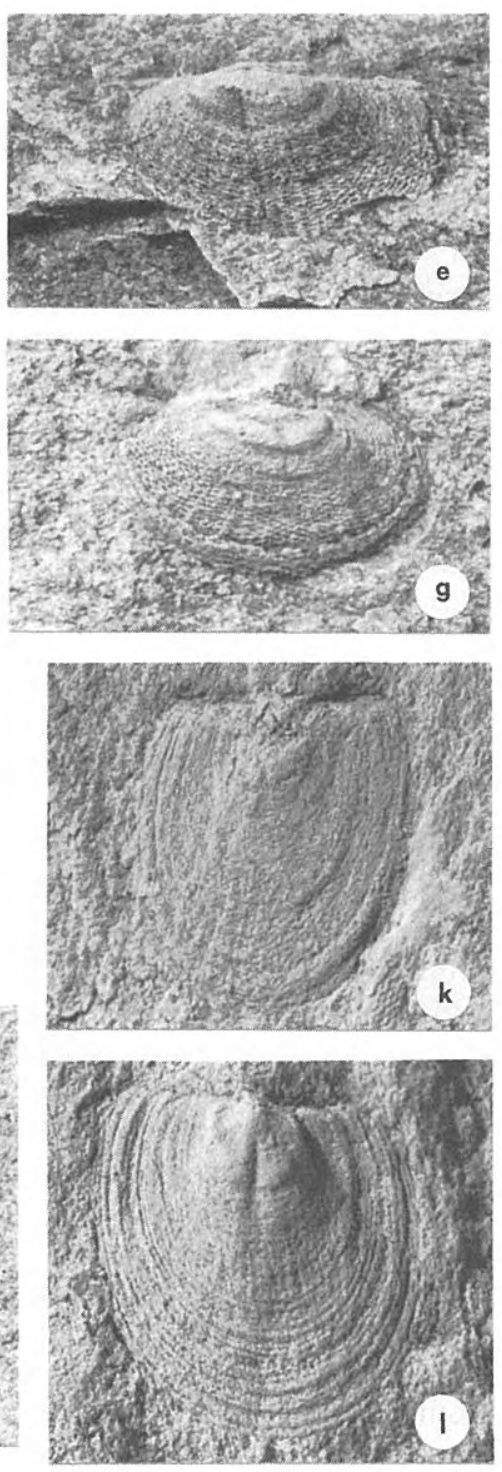
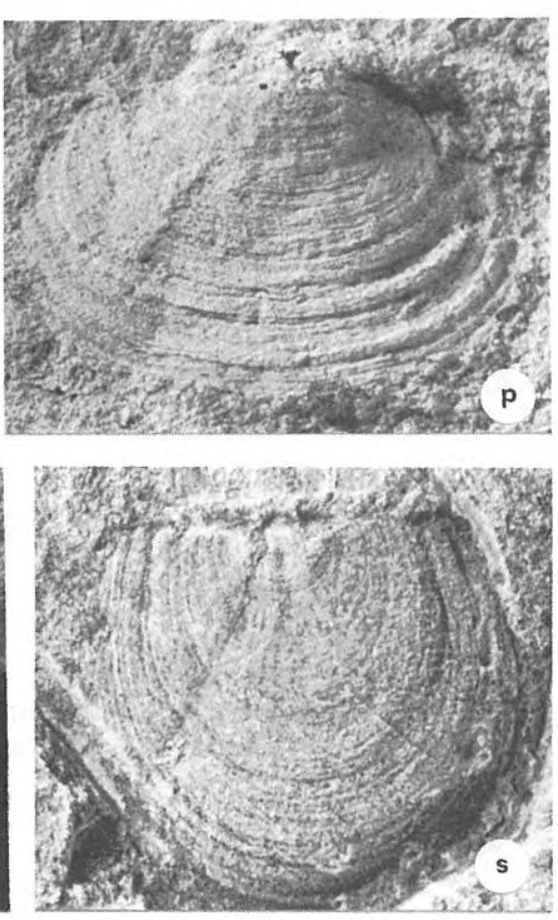

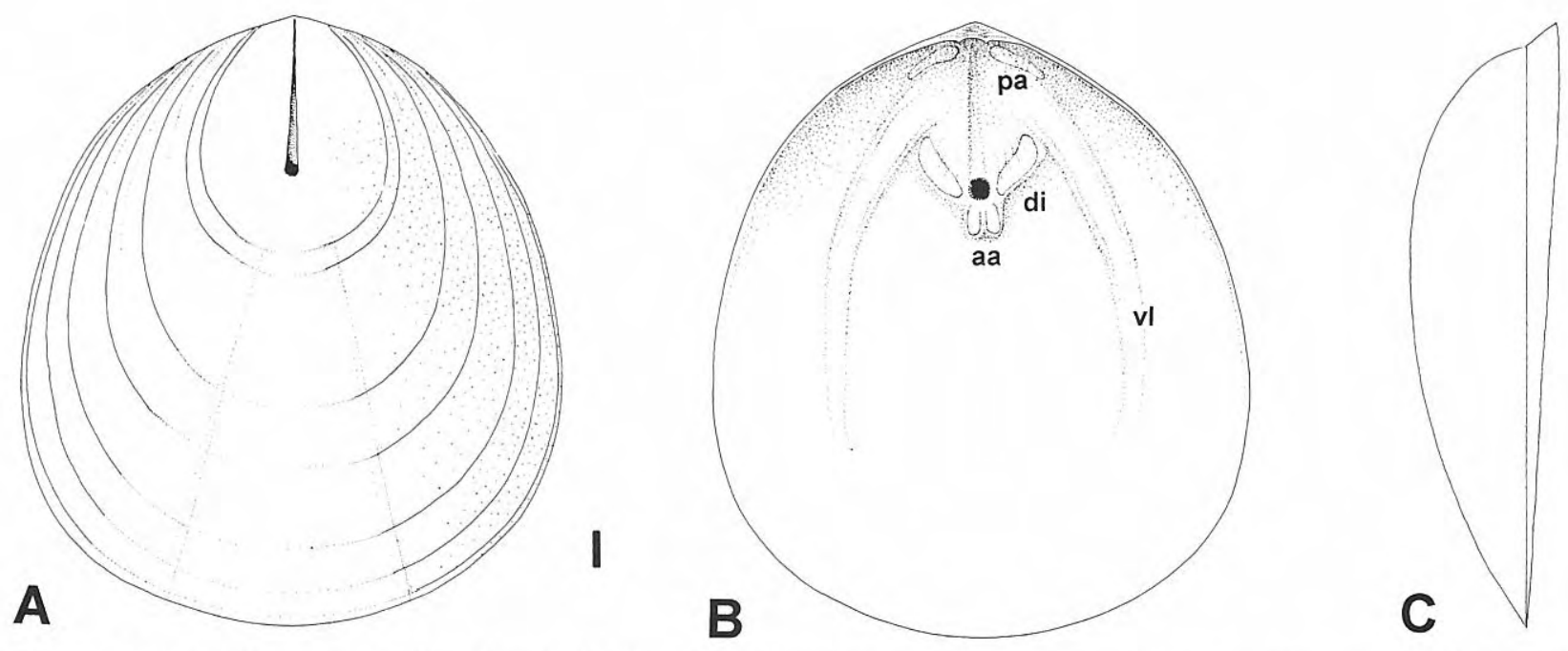

Figure 7. Trematobolus simplex (Vogel, 1962). Reconstruction of exterior of ventral valve (A), interior of ventral valve (B) and lateral profile of the shell (C). aa - paired scars of anterior adductors, di - paired scars of diductors, pa - paired scars of posterior adductors, vl - vascula lateralia. Bar equal $1 \mathrm{~mm}$.

curved margins of the valve. No sign of sulcus, anterior margin rectimarginate. Dorsal valve broadly semicircular, about 60 percent as long as wide or even longer, maximum width posterior to midlength. Posterior margin straight, cardinal extremities rectangular in medium-sized specimens but obtuse in adults. Lateral and transverse profiles of the valve weakly convex.

Interior of both valves unknown.

Ornamentation of regularly arranged, prominent concentric fila, evenly increasing in size anteriorly, sometimes slightly undulating. Anterior half of some valves bears few concentric rugellae of uneven size. There are no superficial pits or radial plications.

\section{Comparison}

The species differs from Dictyonina radioplicata $\mathrm{sp}$. n. by a larger size, an absence of superficial pits and radial plications, and by more prominent concentric growth lines. The absence of radial plications distinguishes the Spanish species from numerous species described and figured by Walcott (1912), especially from Micromitra stissingensis (Dwight), M. sculptilis (Meek) and $M$. pealei (Walcott). The size and ornamentation of Micromitra sp. is rather similar to M. phillipsi (Holl) from the Upper Cambrian of England (Davidson, 1866) but more detailed comparison is impossible.

\section{Occurrence}

Middle Cambrian red beds. Mid-Leonian to Caesaraugustan stages. Mansilla and Murero Formations (Villafeliche, Murero and Mesones localities).
CLASS OBOLELLATA Williams, Carlson, Brunton, Holmer and Popov, 1996

ORDER OBOLELLIDA Rowell, 1965

Superfamily Obolelloidea Walcott and Schuchert, 1908

Family Trematobolidae, Popov and Holmer, 2000

Genus Sibiria Gorjansky, in Pelman, 1977

Type species: Sibiria magna Gorjansky, in Pelman, 1977.

\section{Sibiria (?) sp.}

Fig. $4 \mathrm{i}-\mathrm{k}$

Material: Four poorly preserved valves. MPZ97/554-556.

\section{Remarks}

Deformed moulds show circular pedicle foramen at the apex of the low, asymetrically conical, transversely oval ventral valve, but no traces of pedicle track in the external surface of the valve. Two divergent trunks of vascula lateralia are poorly preserved, but there are no imprints of muscle scars. The general morphology is similar to the Siberian species Sibiria magna, but closer comparison remains impossible.

\section{Occurrence}

Benalija Beds, Sierra Morena. Lower Cambrian (middle Marianian). Rio El Viar and Arroyo Tamujar localities.

\section{Genus Trematobolus Matthew, 1893}

Type species: Trematobolus insignis Matthew, 1893.

igure 8. a-i. Trematobolus simplex (Vogel). a. ventral valve, internal mould, MPZ97/497, x4.5. b. ventral valve, external mould showing pedicle track, MPZ97/498, x4.5. c. ventral valve, internal mould, MPZ97/499, x4.5. d. ventral valve, internal mould, MPZ97/500, x4.5. e. ventral valve, exterior, latex cast, MPZ97/501, x4.5. f. ventral valve, internal mould, MPZ97/502, x4.5. g. ventral valve, exterior, latex cast, MPZ97/503, x4.5. h. ventral valve, internal mould, MPZ97/504, x4.5. i. dorsal valve, internal mould, MPZ97/505, x4.5. j-m. Jamesella sp. j. dorsal valve, internal mould, MPZ97/457, x3.0. k. dorsal valve, internal mould, MPZ97/458, x3.0. 1. dorsal valve, internal mould, MPZ97/459, x3.0. m. dorsal valve, external mould, MPZ97/460, x3.0. 

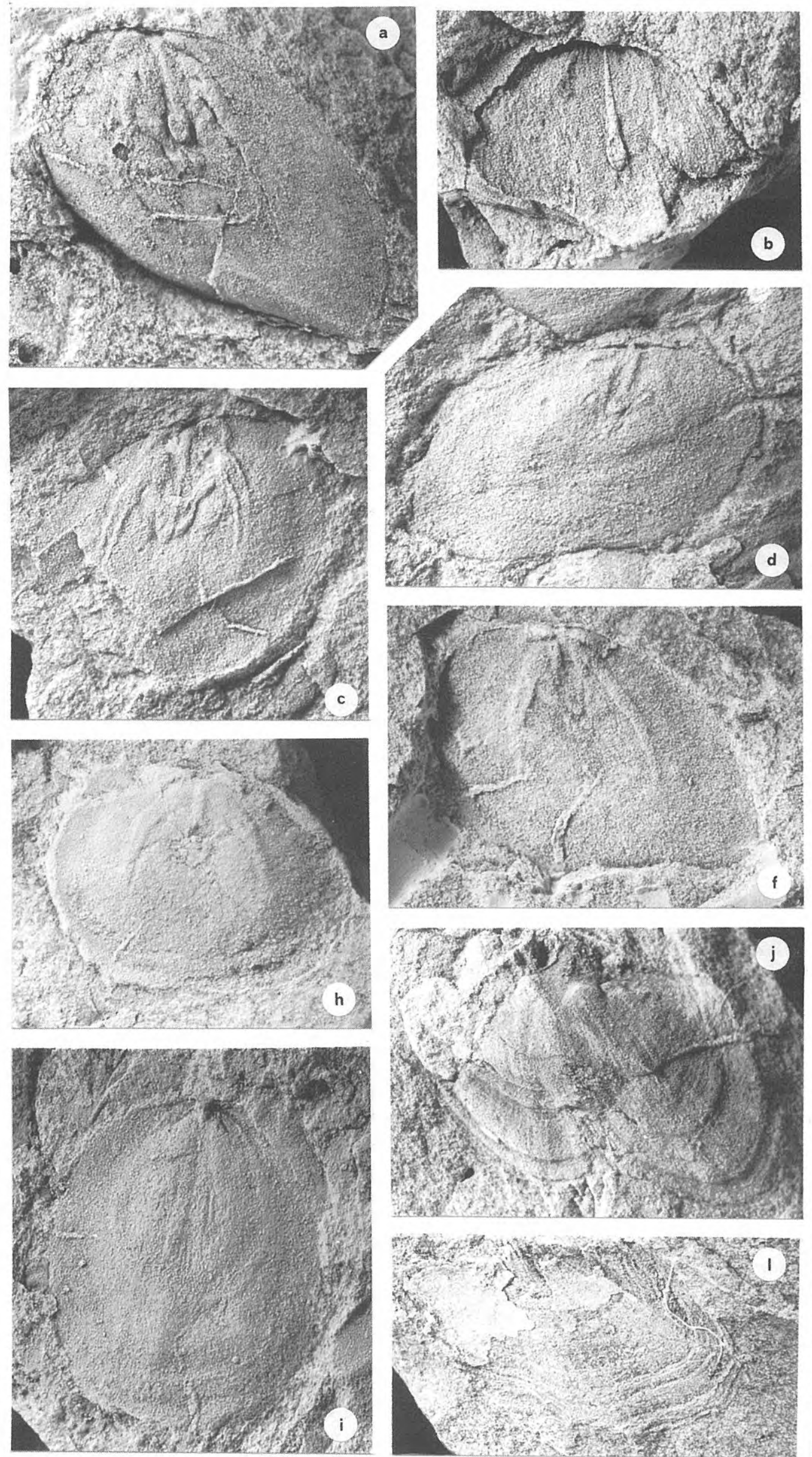
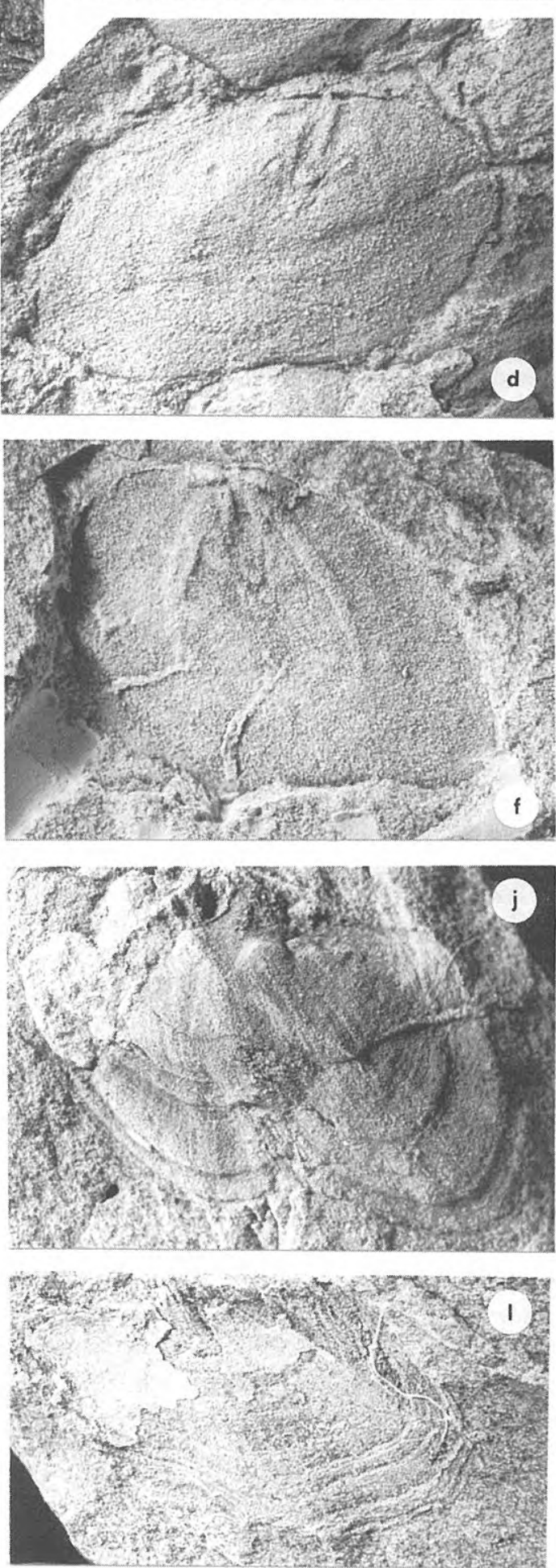
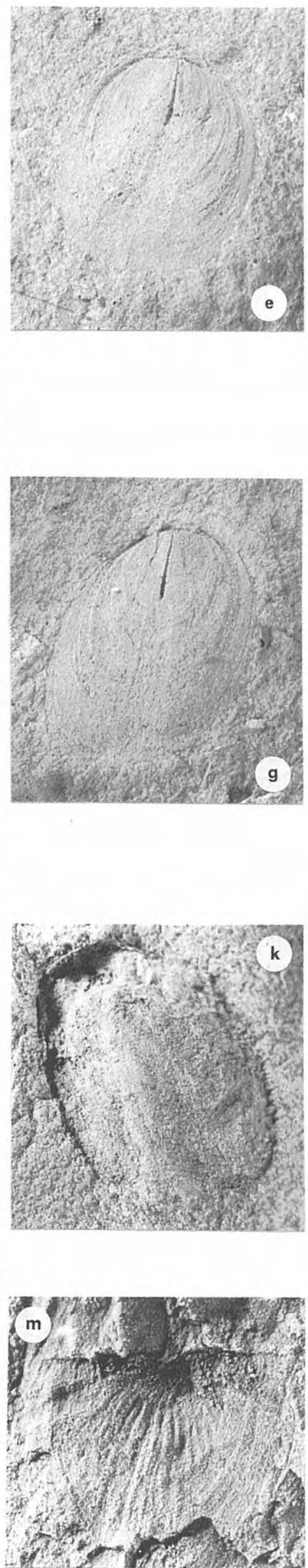

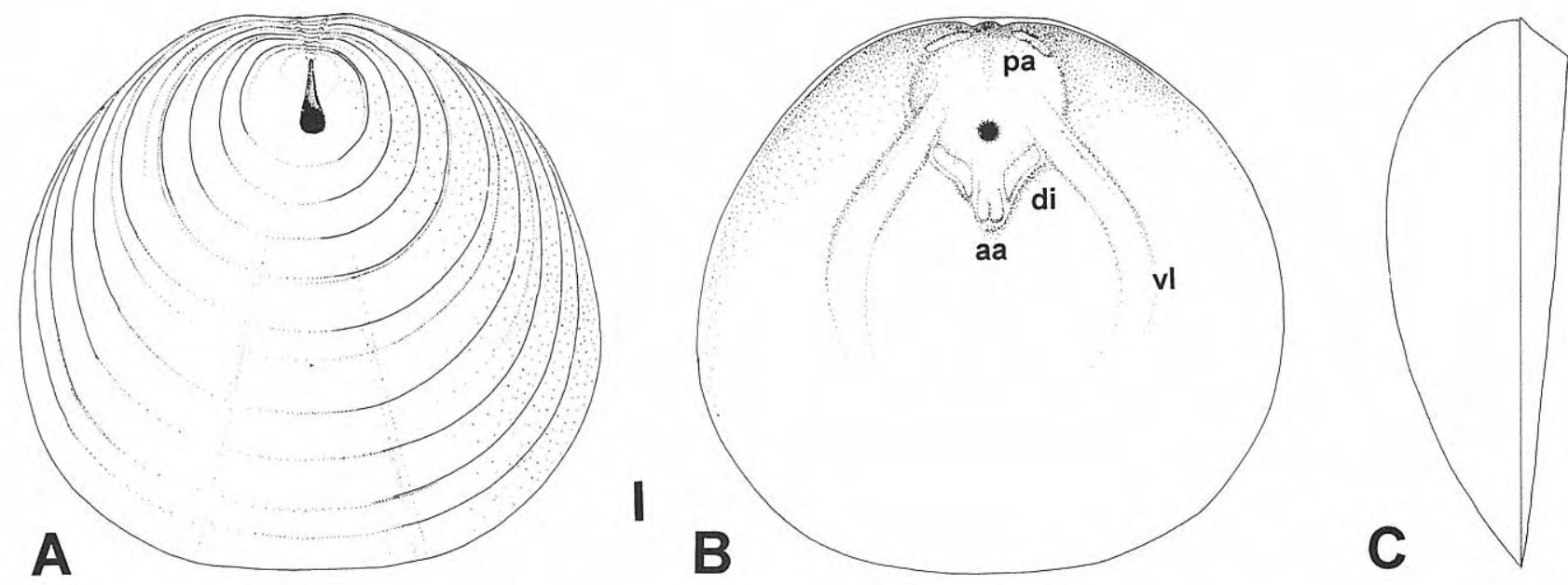

Figure 9. Trematobolus borobiensis sp. n. Reconstruction of exterior of ventral valve (A), interior of ventral valve (B) and lateral profile of the shell (C). aa - paired scars of anterior adductors, di - paired scars of diductors, pa - paired scars of posterior adductors, vl - vascula lateralia. Bar equal $1 \mathrm{~mm}$.

\section{Remarks}

The genus Trematobolus Matthew is widespread near the top of the Lower Cambrian and in the basal Middle Cambrian. Its occurrence is documented from North America (Matthew, 1893; Walcott, 1912; Rowell, 1962), and Siberia (Gorjansky et al., 1964; Pelman, 1977). In the Mediterranean area the genus was reported by Richter and Richter (1941) from Palestine, by Vogel (1962), Havlícek and Kriz (1978), Mergl and Liñán (1986) from Spain, and Geyer and Mergl (1995) from Morocco.

Trematobolus Matthew is a complicated genus; its morphology is fairly simple but it seems rather variable within a particular species (Geyer and Mergl, 1995). Nevertheless, the attitude of the pseudointerarea and the shape of the pedicle track as well as the position of the internal pedicle foramen can be used for a separation of particular species. The morphology of the type species and the data about the occurrence of the species Trematobolus pristinus (Matthew) need careful revision.

The Spanish and the Moroccan occurrences of Trematobolus are well dated. The long stratigraphical range of the Spanish species (upper Lower Cambrianlower Middle Cambrian) make possible the recognition of evolutionary changes; during the interval, the ventral pseudointerarea changes from procline to apsacline, the pedicle foramen migrates anteriorly and ornamentation of weak radial plications develops gradually on the shell surface, being otherwise absent in the older species. On the other hand, the Trematobolus-species known from Morocco show the reversal morphological changes. The species with catacline pseudointerarea and rather short pedicle track (Trematobolus serotinus Geyer and Mergl, and T. cleidrius Geyer and Mergl) have limited geographical occurrences and their stratigraphical position is restricted to the basal Middle Cambrian (Cephalopyge notabilis Zone) (Geyer and Mergl, 1995). Trematobolus splendidus Geyer and Mergl has longer stratigraphic range (Hupeolenus, Cephalopyge notabilis and Ornamentaspis frequens zones). Unfortunately, the Spanish specimens of Trematobolus are generally poorly preserved. This is a major reason, why only part of the available specimens are determined at species level with confidence.

\section{Trematobolus simplex (Vogel, 1962)}

Fig. 7, Fig. 8a-i

1962 Trematobolus sp.; Vogel, pl. I, figs. 2-4

1962 Lamellodonta simplex n. g., n. sp.; Vogel, p. 216, pl. 1, figs. 1, 5-9, pl. 2, figs. 1-4, 7-9, pl. 3, figs. 1,2,4,5, pl. 4, fig.2.

1969 Lamellodonta simplex Vogel, 1962; Newell, p. N400, fig. D8.4.

1975 Lamellodonta simplex Vogel, 1962; Pojeta, pl. 1, figs. 5-7, pl. 4 , fig. 7.

1978 Trematobolus simplex (Vogel, 1962); Havlíček and Kř́íz, p. 974, 975, pl. 1, figs. 1-16.

1983 Trematobolus simplex (Vogel, 1962); Hernández et al., p. 9.

1986 Trematobolus simplex (Vogel, 1962); Mergl and Liñán, p. 170 (partim), pl. 2, figs.1-5.

1995 Trematobolus simplex (Vogel, 1962); Geyer and Mergl, p. 208 (partim).

Material: Two hundred specimens. MPZ96/500-699, MPZ97/484-494; MCR 12974 and 12976b in the Biologie Katedra of Zapadoceská University Czech Republic.

Description: See Havlíček and Kříž (1978).

\section{Remarks}

All available specimens of T. simplex (Vogel) are strongly deformed, but the apsacline ventral pseudointerarea and a slender, long and almost parallel sided pedicle track are notable in the better preserved specimens from the Murero locality. The ventral valve interior shows a median groove running from the posterior margin toward the internal pedicle foramen, which is located between and slightly anterior to diductor impressions. These features clearly distinguish Trematobolus simplex (Vogel) from its probable ancestor 
T. borobiensis sp. n. However, the more deformed specimens cannot be determined with much confidence.

\section{Occurrence}

Lower-Middle Cambrian (Bilbilian-Leonian), Valdemiedes Formation. Murero, Jarque and Villafeliche localities.

\section{Trematobolus borobiensis $\mathrm{sp} . \mathrm{n}$.} Fig. 9, Fig. 10a-f, i-p

1995 Trematobolus simplex (Vogel, 1962); Geyer and Mergl, p. 208 (partim), figs. 14.1-14.2, 14.3-14.6.

Derivatio nominis. Borobia locality, Soria province.

Holotype: Ventral valve, external mould figured on Fig. $10 d$, deposited in the collections of the Museo Paleontológico de la Universidad de Zaragoza, Spain (MPZ97/486).

Paratype: Ventral valve, internal mould, figured on Fig. 10e, deposited in the collections of the Museo Palentológico de la Universidad de Zaragoza, Spain (MPZ97/487).

Type horizon: upper Lower Cambrian (Bilbilian). Daroca Formation. Borobia 1 section, level 38.

Type locality: Iberian Chains, Borobia (Soria province).

Material: Several dozen specimens, mostly fragmental, with prevalence of ventral valves. Specimens preserved as internal and external moulds in calcareous sandstones. MPZ97/484-494.

Diagnosis: Species of Trematobolus characterized by the median sector that is smooth, the median shape of the ventral pseudointerarea which is catacline in juvenile shells becoming procline in adult specimens, the pedicle that is broadly triangular with a large pedicle foramen, the position of pedicle foramen which is located near or slightly posterior to the midlength of the visceral field and the visceral field between the internal pedicle foramen and the posterior margin which is absent in the new species.

\section{Description}

Shell large, thick-walled, dorsibiconvex. The largest specimens more than $16 \mathrm{~mm}$ in width.

Ventral valve subcircular in outline, as long as wide or slightly wider than long, the maximum width anterior to the midlength. Posterior slope of the valve steep, with a small, narrowly triangular pseudointerarea. Interarea catacline in minute shells of young specimens but steeply procline in adults. Lateral profile of the anterior slope is feebly convex, anteriorly shell surface becomes flat. Transverse profile gently convex, with flattened median sector. A broad, narrowly triangular sector with obscure borders extends anteriorly from the apex but the sector never has a form of shallow sulcus. Anterior margin less curved than lateral margins. Hinge line short, straight, equal to 20 percent of the maximum shell width. Pedicle track some 20 percent as long as valve, narrowly drop-like in outline, extending from the top of the apex, rapidly widening anteriorly. Pedicle track rather shallow, less than 30 percent of the shell-wall thickness. A large, circular pedicle foramen penetrates the shell wall obliquely, with internal opening larger than its external diameter.

Dorsal valve transversely oval, some 90 percent similar in length to width, moderately convex in transverse profile. The valve is deepest at the posterior third, its convexity decreases evenly toward front margin. A flattened median sector is distinct in large specimens.

Ornamentation of concentric regularly spaced growth lines, with a few poorly defined growth lamellae. The surface of the ventral interarea is covered by distinct, densely crowded growth lines crossed by two deep radial furrows. Radial ornamentation absent in specimens from the Huérmeda and Daroca formations, but some stratigraphically upper specimens from the overlied Valdemiedes Formation have a pair of weak and narrow plications bordering the flattened median sector of the ventral valve.

Ventral interior with a distinct, broadly triangular visceral field bearing the distinct impressions of diductors and anterior adductors. Vascula lateralia broad, deeply impressed, parallel with the lateral margins. Internal pedicle foramen rather large, located slightly posterior to the midlength of visceral field. Impressions of posterior adductors are small, transverse and distinct.

Dorsal valve interior poorly known, with weak muscle impressions and distict vascula media and vascula lateralia.

\section{Comparison}

The new species was confused with Trematobolus simplex (Vogel) by previous authors (Mergl and Liñán, 1986, Geyer and Merg1, 1995). However, Trematobolus simplex differs by a larger shell size and its median sector which is commonly bordered by radial plications, while median sector of $T$. borobiensis sp. n. is smooth, rarely with an obscure pair of plication present in specimens included in stratigraphically uppermost levels. A significant difference is the shape of the ventral pseudointerarea; this is invariably apsacline and large in Trematobolus simplex while in T. borobiensis is catacline in juvenile shells becoming procline in adult specimens. The pedicle track of Trematobolus simplex is narrow, and anteriorly limited by a rather small pedicle foramen, while the pedicle track of $T$. borobiensis is broadly triangular with a large pedicle foramen. The position of the internal pedicle foramen is another distinguishing feature; Trematobolus borobiensis has the foramen located near or slightly posterior to the midlength of the visceral field while this is located much more anteriorly in $T$. simplex, often even anterior to adjacent diductor impressions. Moreover, the visceral field between the internal pedicle foramen and the posterior margin of Trematobolus simplex bears an elongate furrow, which is absent in $T$. borobiensis. Posterior muscle scars of Trematobolus borobiensis are fairly weak while the scars of $T$. simplex are more prominent. 
Minute morphological variations can be traced also in specimens assigned to Trematobolus borobiensis sp. $\mathrm{n}$.; except for differences in the radial ornamentation noted above, the pedicle foramen in the specimens from the Daroca Formation is a rather thin tube, passing through the shell-wall obliquely while the specimens from the Valdemiedes Formation possess foramen of a larger diameter, with a tube almost perpendicular to the shell surface. In addition, the specimens from the Valdemiedes Formation have less divergent posterior trunk of ventral vascula lateralia.

Geyer and Mergl (1995) have described three new species of Trematobolus from the early Middle Cambrian (Cephalopyge notabilis Zone) of Morocco. Among them, only Trematobolus serotinus Geyer and Mergl, possesses catacline to even procline ventral pseudointerarea as $T$. borobiensis sp. n., but the new species can be distinguished by a much broader pedicle track (narrowly drop-like), narrower canals of the vascula lateralia and in having internal pedicle foramen located more posteriorly. Trematobolus cleidrius Geyer and Mergl is similarly shaped but with a longer pedicle track, no sulcus and obscure radial ornamentation, but differs mainly by a much more anteriorly situated internal pedicle foramen at the anterior point of a distinct elongate groove on the ventral visceral area.

\section{Occurrence}

Lower Cambrian (Bilbilian), the Huérmeda, Daroca and Valdemiedes formations. Borobia and Jarque localities.

\section{Phylogeny}

The two species of Trematobolus known from the Iberian Chains have a different stratigraphical record and they coincide during a very short interval. Trematobolus borobiensis appears at the top of the Huérmeda Formation, is abundant in the Daroca Formation and disappears near the top of the Valdemiedes Formation (Bilbilian age). Trematobolus simplex is found only in the upper part of the Valdemiedes Formation (Hamatolenus ibericus-Eoparadoxides mureroensis Zones). The very common characteristics of the two species, the morphological changes through the stratigraphical record and its stratigraphical relief suggest that $T$. borobiensis may be considered as the ancestor of $T$. simplex.

\section{Trematobolus ef. borobiensis sp. $\mathrm{n}$.} Fig. $10 \mathrm{~g}-\mathrm{h}$
1986 Trematobolus simplex (Vogel, 1962); Mergl and Liñán, p. 170 (partim), pl. 2, figs.6-7.

\section{Remarks}

Specimens descrived by Mergl and Liñán (1986) from the Jarque section (DPZ176, DPZ179) have interior similar to T. borobiensis but probable apsacline to even orthocline pseudointerarea; thus, they are referred here as T. borobiensis with some doubts

CLASS RHYNCHONELLATA Williams, Carlson, Brunton, Holmer and Popov, 1996

ORDER PROTORTHIDA Schuchert and Cooper, 1932 SUBORDER PROTORTHIDINA Schuchert and Cooper, 1931

Superfamily Protorthoidea Schuchert and Cooper, 1931

Family Protorthidae Schuchert and Cooper, 1931

Genus Jamesella Walcott, 1905

Type species Orthis perpasta Pompeckj, 1896.

\section{Jamesella sp.}

Fig. 8j-m

Material: Two internal moulds and one external moulds of dorsal valve. MPZ97/457-460.

\section{Description}

Shell large, about $15 \mathrm{~mm}$ wide, subrectangular in outline, dorsibiconvex.

Dorsal valve about 80 percent as long as wide, widest at the hinge line, with a weak fold and shallow emargination at front margin. Cardinal extremities acute to subrectangular in large valves. Dorsal interarea anacline, moderately high, delthyrium open, broadly triangular. Dorsal valve interior with swollen bottom of the nothothyrial cavity and a distinct anterior border of the notothyrial platform. Distinct brachiophores absent.

Ornamentation of coarse radial ribs, more distinct in median sector of the valves than on flanks. Growth lamellae unevenly spaced and more crowded anteriorly.

\section{Remarks}

The rarity of material which is strongly affected by a tectonical deformation does not enable better taxonomic assignment. The species very likely belongs to Protorthidae Schuchert and Cooper; the general shape of the shell is similar to the shape of the genera Jamesella Walcott and Saesorthis Mergl and Geyer, both from the

Figure 10. a-f, i-p. Trematobolus borobiensis sp. n. a. ventral valve, exterior, latex cast, MPZ97/484 x5.5. b, c. ventral valve, exterior and lateral view, latex cast, MPZ97/485, x4.5. d. ventral valve, external mould, holotype MPZ97/486, x4.5. e. ventral valve, internal mould, MPZ97/487, x4.5. f. ventral valve, internal mould, paratype MPZ97/488, x4.5. i. dorsal valve, internal mould, MPZ97/489, x5.5. j. ventral valve, internal mould, MR C 12976, x6.0. k. ventral valve, internal mould, MPZ97/490, x5.0. I. ventral valve, internal mould, MR C 12974b+, x6.0. m. ventral valve, internal mould, MPZ97/491, x4.5. n. ventral valve, internal mould, MPZ97/492, x4.5. o. ventral valve, internal mould, MPZ97/493, x4.5. p. ventral valve, internal mould, MPZ97/494, x4.5. g-h: Trematobolus cf. borobiensis sp. n. g. ventral valve, external mould, DPZ 179, x4.5. h. ventral valve, internal mould, DPZ 179, x4.5. 

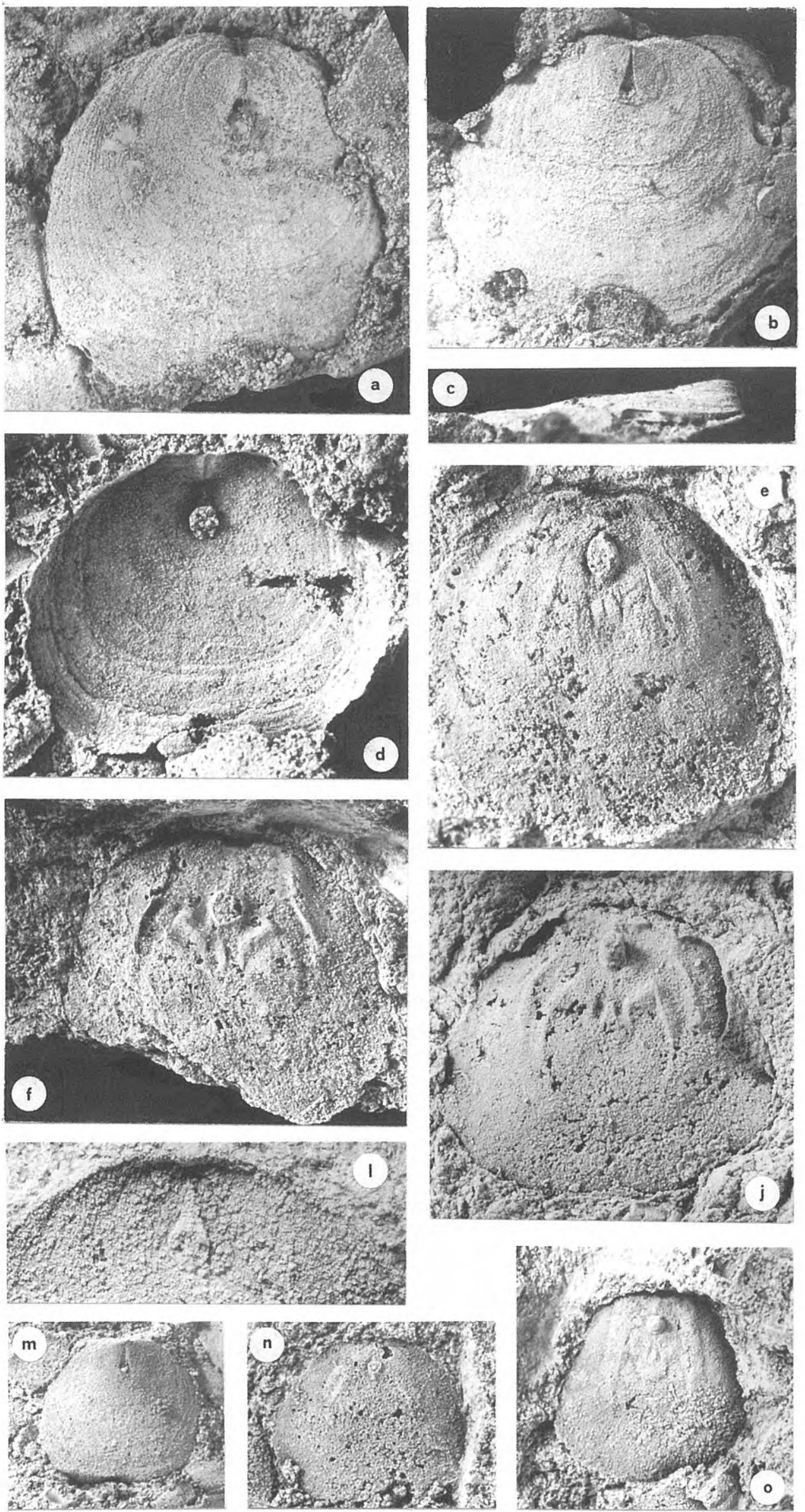
$+2,10$

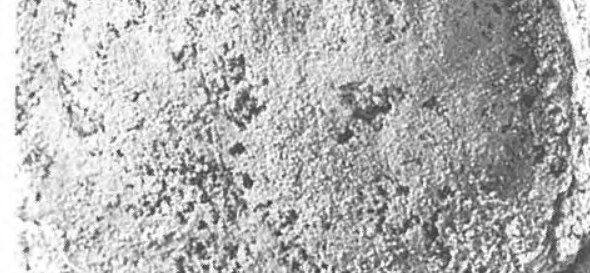

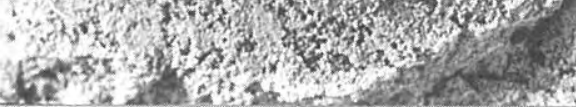
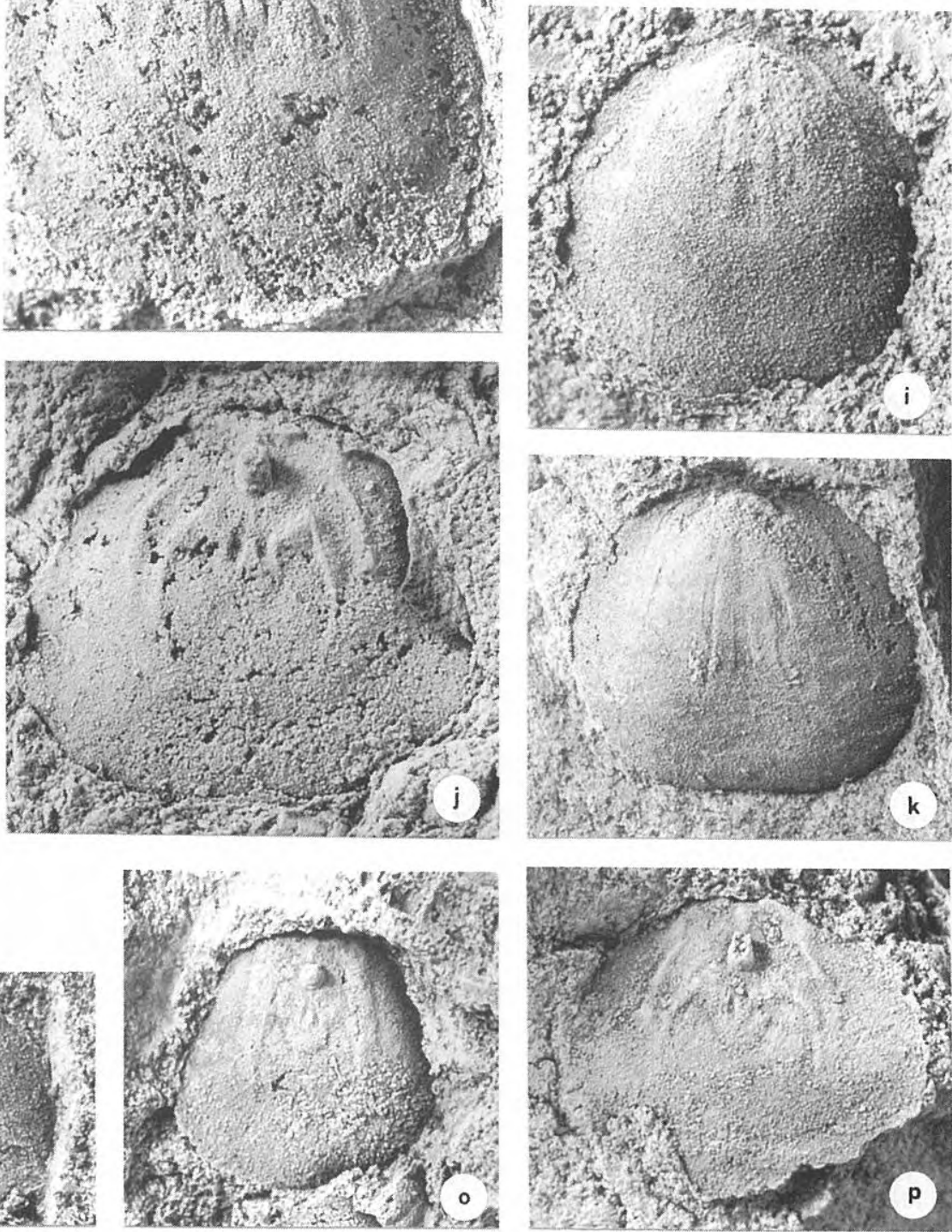
early Middle Cambrian of Bohemia and Morocco, respectively. Jamesella iberica Gil Cid and Melou from the Middle Cambrian of the Ossa Morena differs by coarser, fewer ribbing (Gil Cid and Melou, 1988).

\section{Occurrence}

Rambla de Valdemiedes 2 section, level 13. Valdemiedes Formation in Murero locality.

\section{CONCLUSIONS}

The integrated analysis of the brachiopod taxonomy, biostratigraphy, fossil assemblages and facies permit us to interpret the brachiopod occurrence of the LowerMiddle Cambrian rocks from Ossa-Morena Zone and Iberian Chains as palaeoeocologicaly induced. Thus the brachiopods are present in reefal, perireefal, inner sublittoral and open sublittoral facies (sensu Liñán, 1995) both in the Ossa-Morena Zone and the Iberian Chains.

In the Ossa-Morena Zone, the first brachiopod assemblage (Paterina) occurs during Lower Ovetian age (Liñán and Mergl, 1983) related to bioherm constructions suggesting reefal and perireefal environments (Perejón, 1994; Moreno-Eiris et al., 1995). In the Marianian age, brachiopods are also present in open sublittoral facies (Acrothele and Obolella) and inner sublittoral facies (Obolella and Sibiria?) as is suggested by the trilobite assemblages (Liñán and Perejón, 1981, Liñán and Mergl; 1983). No brachiopods have been found in the Bilbilian age while in Middle Cambrian times there are few brachiopods (Jamesella iberica and Yorkia zafrensis Gil Cid and Melou, 1988) in open sublittoral facies with the trilobites Sao aff. hirsuta, Paradoxides rohanovicus, Jincella? sp, Ctenocephalus sp. and Condylopyge sp. (Liñán et al., 1996b). These data suggests that brachiopods from Sierra Morena successively colonized reefal ecosystems and sublittoral biomas during early Early Cambrian. If they are finally not present in upper Lower Cambrian rocks of Ossa-Morena Zone, it is probably due to the Daroca regression effect which induced the disappearance of the carbonate platform in the south of Spain. Open sublittoral conditions and distality seem to be the explanation of sporadic brachiopod occurrence in the wide Middle-Upper Cambrian siliciclastic platform of Ossa-Morena.

In the Iberian Chains, although some obolellid brachiopods are found from the Dolomía de Ribota Formation associated with Marianian trilobites, the Cambrian brachiopod facies seems to be abundant from the upper part of the Huérmeda Formation (Bilbilian) followed by an almost continuous record until the top of the Murero Formation (Caesaraugustan).

The later record of Lower Cambrian brachiopods in the Iberian Chains than in the Ossa-Morena Zone may be due to adverse palaeoecological conditions in Iberian Chains where lower Lower Cambrian strata were deposited on a shallower siliciclastic platform under high energy conditions.

The brachiopods from the Iberian Chains also occur mainly in sublittoral facies. In these facies two brachiopod assemblages, which can sometimes be found together, may be recognized: a shallower Trematobolus assemblage and a relatively deeper Dictyonina Redlichella assemblage that may be used as marker of minor sea level changes. They not only reflect some depth differences but also a relative decrease of water energy for the Dictyonina-Redlichella assemblage.

The Trematobolus assemblage which firstly occurs in the Lower Bilbilian (late Lower Cambrian), is progresively replaced by the Dictyonina-Redlichella assemblage. Of the two species from the Iberian Chains, T. borobiensis sp. $\mathrm{n}$. was common in siliciclastic habitats while $T$. simplex preferred bottoms with carbonate or mixed fine sediments.

Finally, it seems higly likely that brachiopods were not affected by the Early-Middle Cambrian extinction and that the Valdemiedes event only produced a decrease in the size of the specimens. It was during the mid Leonian regression when the species of Trematobolus disappeared coinciding with a biotic crisis in the benthic and pelagic communities. The transgressive pulse following the mid Leonian regression involved progresively deeper conditions and the predominance of the Dictyonina-Redlichiella assemblage in the Iberian Chains during the Caesaraugustan stage.

\section{ACKNOWLEDGEMENT}

The research was partly supported by the Projects PB960744 and BTE2000-1145-CO2-CO1 of the Spanish D.G.E.S. and a grant No. RAK 2005601: Biodiversity and function of ecological systems of the Grant Agency of the Academy of Sciences of the Czech Republic. We are very grateful to María Eugenia Dies, Eduardo Martín, Joel García Aller, Enrique Oliver and Silvia Yuste for their help during the work. Thanks are due to Dr. Gozalo (Valencia University), Dr. Villas (Zaragoza University) and Dra. Martínez Chacón (Oviedo University) for their comments about the original manuscript and its improvement. And finally thanks to Mr. Tim Cooper for revising the English text.

\section{REFERENCES}

Álvaro, J. 1995. Propuesta de una nueva unidad litoestratigráfica para el Cámbrico Medio-Superior de las Cadenas Ibéricas (NE de España): El Grupo Acón. Boletín de la Real Sociedad Española de Historia Natural (Geología), 90, 95-106.

Álvaro, J. y Liñán, E. 1997. Nuevos datos acerca del Bilbiliense Inferior en la Península Ibérica y su correlación con áreas próximas. Revista Española de Paleontología, 12, 277-280.

Álvaro, J., Gozalo, R., y Liñán, E. 1993a. Bioestratigrafía del límite Cámbrico Inferior-Medio de Ateca (Cadena Ibérica Occidental, España). Revista Española de Paleontología, $\mathbf{n}^{\circ}$ extr., 49-57. 
Álvaro, J., Gozalo, R., Liñán, E. and Sdzuy, K. 1993b. The palaeogeography of the northern Iberia at the LowerMiddle Cambrian transition. Bulletin de la Société géologique de France, 164, 843-850.

Álvaro, J., Liñán, E., Vennin, E. and Gozalo, R. 1995. Palaeogeographical evolution within a passive margin with syndepositional faulting: The Marianian deposits (Lower Cambrian) of the Iberian Chains (NE Spain). Neues Jahrbuch für Geologie und Paläontologie, Monatshefte, 1995 (9), 521-540.

Barrande, J. 1879. Systême Silurien du centre de la Bohême. Praha, $226 \mathrm{pp}$

Cobbold, E.S. 1921. The Cambrian horizons of Comley (Shropshire) and their Brachiopoda, Pteropoda, Gasteropoda. Quarterly Journal of the Geological Society of London, 304, 325-386.

Cooper, G.A. 1942. New genera of North America brachiopods. Journal of the National Academy of Sciences, 32 (8), 228-235.

Courtessole, R., Pillet, J. et Vizcaïno, D. 1988. Stratigraphie et Paléontologie du Cambrien moyen greseux de la Montagne Noire (versant meridional). Mémoire de la Société d'Etudes Scientifiques de l'Aude, $55 \mathrm{pp}$.

Davidson, T. 1866. A monograph of the British fossil Brachiopoda, Silurian Brachiopoda, 1, London, 1-88.

Dereims, A. 1898. Note sur les terrains palézoiques d'Espagne. Recherches geologiques dans le Sud de l'Aragón. Ann. Hébert, t.II, 199 pp. Lille.

Fatka, O., Mergl, M., Šarič R. and Kordule V. 1992. Early Middle Cambrian fauna in Central Bohemia. Věstník Českého Geologického Ústavu, 67 (2), 85-95.

Fricke, W. 1941. Die Geologie des Grennzgebietes zwischen nordöslicher Sierra Morena und Extremadura. Diss. Univ. Berlín. 1-91. (Unpublished).

Gámez Vintaned, J.A. y Mayoral Alfaro, E. 1992. Primeras aportaciones a la Paleoicnología del Grupo Murero (Cámbrico inferior-medio) en Murero (Provincia de Zaragoza. Cadena Ibérica Occidental). Geogaceta, 12, 100-102.

Gámez, J. A., Fernández-Nieto, C., Gozalo, R., Liñán, E., Mandado, J. y Palacios, T. 1991. Bioestratigrafía y evolución ambiental del Cámbrico de Borobia (Provincia de Soria, Cadena Ibérica Oriental). Cuadernos do Laboratorio Xeolóxico de Laxe, 16, 251-271.

Geyer, G. and Merg1, M. 1995. Mediterranean representatives of the obolellid Trematobolus Matthew (Brachiopoda) and a review of the genus. Paläontologische Zeischrift, 69 (1/2) 179-209.

Gil Cid, M. D. et Melou, M. 1988. Brachiopodes du Cambrien moyen de Zafra (Province de Bajadoz, Espagne). Géologie Méditerranéenne, 12-13 (3-4), 197-205.

Gozalo, R. 1995. El Cámbrico de las Cadenas Ibéricas. In: Memorias de las IV Jornadas Aragonesas de Paleontología: "La expansión de la vida en el Cámbrico". Libro homenaje al Prof. Klaus Sdzuy. (Eds. J.A. Gámez Vintaned y E. Liñán). Inst. Fernando el Católico, Zaragoza, 137-167.

Gozalo R. y Liñán, E. 1988. Los materiales hercínicos de la Cordillera Ibérica en el contexto del Macizo Ibérico. Estudios geológicos, 44, 399-404.
Gozalo, R. and Liñán, E. 1995. Leonian (early Middle Cambrian) Paradoxides biostratigraphy. Beringeria, Special Issue 2, 169-171.

Gozalo, R. y Liñán, E. 1996. Nueva especie de Conocoryphidae (Trilobita). Cámbrico Medio de las Cadenas Ibéricas (NE de España). Revista Española de Paleontología, 11, 247-250.

Gozalo, R., Liñán, E. y Álvaro, J. 1993. Bioestratigrafía del Cámbrico Medio de Villafeliche (Prov. Zaragoza, España). Revista Española de Paleontología, no extr., 49-57.

Gozalo, R., Liñán, E. and Sdzuy, K. 1996. The Lower and Middle Cambrian of Murero and Villafeliche. (West Asturian-Leones Zone. Western Iberian Chain). In: II Field Conference of the Cambrian Stage Subdivision Working Groups. International Subcommission on Cambrian Stratigraphy. Spain, 13-21 September 1996. Field Trip Guide and Abstracts (Eds. E. Liñán, J.A. Gámez Vintaned and R. Gozalo). Universidad de Zaragoza, 57-72.

Gorjansky, V. Y., Egorova, L. I. and Savitskij, V. E. 1964. O faune nizhnego kembrija sregnego sklona Anabarskogo schtchita. Utschebnyje zapiski naustschnoissledovatelskogo instituta geologii Arktiki, seria paleonologija i biostratigrafija, 4, 5-32.

Havlíček, V. 1971. Stratigraphy of the Cambrian of Central Bohemia. Sborník geologických Vĕd, Geology, 20, 7-52.

Havlíček, V. and Kř́́̌̆, J. 1978. Middle Cambrian Lamellodonta simplex Vogel: bivalve turned brachiopod Trematobolus simplex Vogel. Journal of Paleontology, 52, 972-975.

Hernández, A., Olivé, A., Moissenet, E., Carls, P., Sdzuy, K. y Kolb, S. 1983. Mapa geológico de España. E.: 1: 50.000. Daroca (465). Instituto Geológico y Minero de España. 76 pp.

Holmer, L. E. and Popov, L. E. 2000. Lingulata. In: Treatise on Invertebrate Paleontology, part H Brachiopoda Revised, vol.2 (Ed. R.L. Kaesler). The Geological Society of America and the University of Kansas, 30157.

Holmer, L. E., Popov, L. E. and Wrona, R. 1996. Early Cambrian lingulate brachiopods from glacial erratics of King George Island (South Shetland Islans), Antarktica. Palaeontologia Polonica, 55, 37-50.

Josopait, V. 1972. Das Kambrium und das Tremadoc von Ateca (Westliche Iberische Ketten, NE Spanien. Münstersche Forschungen Geologie und Paläontologie, 23, $121 \mathrm{pp}$.

Linnarsson, J. G. O. 1876. Brachiopoda of the Paradoxides beds of Sweden. Bihang till Konkliga Svenska Vetenskaps. Akademiens Handlingar, 3 (12), 1-34.

Liñán, E. 1978. Bioestratigrafía de la Sierra de Córdoba. Tesis doctorales de la Universidad de Granada, 191, Universidad de Granada, Granada, 1-212.

Liñán, E. 1995. Una aproximación a los ecosistemas marinos cámbricos In: Memorias de las IV Jornadas Aragonesas de Paleontología: "La expansión de la vida en el Cámbrico. Homenaje al Prof. Klaus Sdzuy" (Eds. J.A. Gámez Vintaned y E. Liñán). Institución "Fernando el Católico", Zaragoza, 27-48. 
Liñán, E. y Gozalo, R. 1986. Trilobites del Cámbrico inferior y medio de Murero (Cordillera Ibérica). Memorias del Museo Paleontológico de la Universidad de Zaragoza, 2, 1-104.

Liñán, E. and Merg1, M., 1983. Lower Cambrian Brachiopods of Sierra Morena, SW Spain. Boletín de la Real Sociedad Española de Historia Natural (Sección Geológica), 80, 207-220.

Liñán, E. y Perejón, A. 1981. El Cámbrico inferior de la "Unidad de Alconera", Badajoz (SW de España). Boletín de la Real Sociedad Española de Historia Natural (Sección Geológica), 79, 125-148.

Liñán, E. and Quesada, C. 1990. Part V Ossa-Morena Zone. 2 Stratigraphy. 2.2 Rift Phase (Cambrian). In: PreMesozoic Geology of Iberia (Eds. R. D. Dallmeyer and E. Martínez García). Springer-Verlag, Berlin, Heidelberg, 259-266.

Liñán, E., Gozalo, R., Gámez, J. A. y Álvaro, J. 1992. Las formaciones del Grupo Mesones (Cámbrico InferiorMedio) en las Cadenas Ibéricas. III Congreso Geológico de España y VIII Congreso Latinoamericano de Geología, Salamanca, Actas, 1, 517-523.

Liñán, E., Perejón, A. and Sdzuy, K. 1993a. The LowerMiddle Cambrian stages and stratotypes from the Iberian Peninsula: a revision. Geological Magazine, 130, 817833.

Liñán, E., Fernández-Nieto, C., Gámez, J. A., Gozalo, R., Mayoral, E., Moreno-Eiris, E., Palacios, T. y Perejón, A. 1993b. Problemática del límite Cámbrico Inferior-Medio en Murero (Cadenas Ibéricas, España). Revista Española de Paleontología, $\mathbf{n}^{\circ}$ extr., 26-39.

Liñán, E., Sdzuy, K., Álvaro, J.J., Gámez Vintaned, J.A. and Gozalo, R. 1996a. September 19. The Jarque section: Lower and Middle Cambrian (West Asturan-Leonese Zone. Eastern Iberian Chain). In: II Field Conference of the Cambrian Stage Subdivision Working Groups. International Subcommission on Cambrian Stratigraphy. Spain, 13-21 September 1996. Field Trip Guide and Abstracts (Eds. E. Liñán, J.A. Gámez Vintaned and R. Gozalo). Universidad de Zaragoza, 57-72.

Liñán, E., Villas E., Gámez-Vintaned, J. A., Álvaro, J., Gozalo, R., Palacios, T. y Sdzuy, K. 1996b. Síntesis paleontológica del Cámbrico y Ordovícico de la Cordillera Ibérica (Cadenas Ibéricas y Cadenas Hespéricas). Revista Española de Paleontología, $\mathbf{N}^{\mathbf{o}}$ Extraordinario, 21-32.

Lotze, F. 1929. Stratigraphie und Tektonik des Keltiberischen Grundgebirges (Spanien). Abhandlungen der Gesellschaft der Wissenschaften zu Göttingen, mathematisch-physikalische Klasse, n. F., 14 (2), 1-320. [Spanish translation by M. San Miguel de la Cámara: Estratigrafía y tectónica de las cadenas paleozoicas celtibéricas. Publicaciones extranjeras sobre Geología de España, 8, 1-313; year 1955].

Lotze, F. 1961. Das Kambrium Spaniens. Teil I: Stratigraphie. Akademie der Wissenschaften und der Literatur, Abhandlungen der mathematischnaturwissenschaftlichen Klasse, 1961 (6), 1-216. [Spanish translation by J. Gómez de Llarena: El Cámbrico de España. Memorias del Instituto Geológico y
Minero de España, 75, 1-256; year 1970].

Matthew, G. F. 1893. Trematobolus. An articulate brachiopod of the inarticulate order. The Canadian Record of Science, 5, 276-270.

M'Coy, F. 1851. On some new cambro-Silurian fossil. Annals and Magazine of Natural History, ser. 2, 8, 387409.

Meek, F.B. 1873. Preliminary palaeontological report. 6th Annual Report of the U.S. Geological Survey of Montana, Idaho, Wyoming and Utah, 429-518.

Mergl, M. 1988. Inarticulate brachiopods of early Middle Cambrian age from the High Atlas, Morocco. Věstník Ústredního Ústavu geologického, 63 (5) 291-295.

Mergl, M. and Liñán, E. 1986. Some Cambrian Brachiopoda of the Cordillera Iberica and their biostratigraphical significance. In: Memorias de las I Jornadas de Paleontología (Ed. E. Villas), Diputación General de Aragón, Zaragoza, 159-180.

Mergl, M. and Šlehoferová, P. 1990. Middle Cambrian inarticulate brachiopods from Central Bohemia. Sborník geologickych Vĕd, Paleontology, 31, 65-10.

Moreno-Eiris, E., Perejón, A., Rodríguez, S. and Falces, S. 1995. Paleozoic Cnidaria and Porifera from Sierra Morena. In: VII International Symposium on Fossil Cnidaria and Porifera, Field Trip D. (Ed. A. Perejón). Universidad Complutense de Madrid, 68 pp.

Newell, N. D. 1969. Lamellodontidae. In: Treatise on Invertebrate Paleontology, Part N, Mollusca 6. Bivalvia: $N$ 400. (Ed. R. C. Moore). Geological Society of America and the University Kansas Press. Lawrence, 30 pp.

Palacios, P. 1893. Reseña geológica de la región meridional de la provincia de Zaragoza. Boletín de la Comisión del Mapa geológico de España, 19, 1-112.

Palacios, T. and Moczydlowska, M. 1998. Acritarch biostratigraphy of the Lower-Middle Cambrian boundary in the Iberian Chains, province of Soria, northeastern Spain. Revista Española de Paleontología, $\mathbf{n}^{\mathbf{0}}$ extr. Homenaje al Prof. Gonzalo Vidal, 65-82.

Pelman, Y. L. 1977. Ranne i srednekembrijskie bezzamkovije brachiopody Sibirskoj platformy. Trudy Instituta Geologii i Geofiziki, 319, 1-167.

Perejón, A. 1994. Palaeogeographic and biostratigraphic distribution of Archaeocyatha in Spain. Courier Forschungs-Institut Senckenberg, 172, 341-354.

Pojeta, J. 1975. Fordilla troyensis Barrande and early pelecypod phylogeny. - Bulletin of American Paleontology, 67 (287), 363-384.

Pompeckj, 1896. Die fauna das Kambrium von Tejrovicund Skrej in Boehmen. Kaiserlich-koenigliche Geologische Reichanstalt, 45, 509-516.

Richter, R. und Richter, E. 1941. Das Kambrium am Toten Meer und die älteste Tethys. Abhandlungen der Senckenbergischen naturforschenden Gesellschaft, 460, $1-50$.

Rowell, A. J. 1962. The genera of the brachiopod superfamilies Obolellacea and Siphonotretacea. Journal of Paleontology, 36, 136-152.

Rowell, A. 1965. Inarticulata. In: Treatise on Invertebrate Paleontology, part H, Brachiopoda, H260-H297. (Ed. 
R.C. Moore). Geological Society of America and the University Kansas Press. Lawrence, 520 pp.

Rowell, A. 1980. Inarticulate brachiopods of the Lower and Middle Cambrian Pioche Shale of the Pioche District, Nevada. University of Kansas, Paleontological Contributions, 98, 1-26.

Salter, J.W. 1866. On the fossils of North Wales. In: Ramsay, A.C. The Geology of North Wales. Memoirs of the Geological Survey of Great Britain, 3, 239-381.

Sampelayo, P. H., 1935. El sistema Cambriano. In: Explicación del nuevo mapa Geológico de España, tomo I, Instituto Geológico y Minero de España, 291-528.

Schmidt-Thomé, M. 1973. Beiträge zur Feinstratigraphie des Unterkambriums in den Iberischen Ketten (NordostSpanien). Geologische Jahrbuch (Reihe B), 7, 3-43.

Schmitz, V. 1971. Stratigraphie und Sedimentologie im Kambrium und Tremadoc der Westlichen Iberischen Ketten nördlich Ateca (Zaragoza), NE-Spanien. Münstersche Forschungen zur Geologie und Paläontologie, 22, 1-123.

Sdzuy, K. 1961. Das Kambrium Spaniens. Teil II: Trilobiten. Akademie der Wissenschaften und der Literatur, Abhandlungen der mathematisch-naturwissenschaftlichen Klasse, 1961 (7-8), 499-690 (217-408).

Sdzuy, K. 1968. Trilobites del Cámbrico Medio de Asturias. Trabajos de Geología, Universidad de Oviedo, 1 (1967), 77-133.

Sdzuy, K. 1971a. Acerca de la correlación del Cámbrico inferior de la Península Ibérica. In: I Congreso HispanoLuso-Americano de Geología Económica, Sección 1 Geología, 2, 753-768.

Sdzuy, K. 1971b. La subdivisión bioestratigráfica y la correlación del Cámbrico Medio de España. In: I Congreso Hispano-Luso-Americano de Geología Económica, Sección 1 Geología, 2, 769-782.

Sdzuy, K. 1995. Acerca del conocimiento actual del Sistema Cámbrico y del límite Cámbrico Inferior-Cámbrico Medio. In: Memorias de las IV Jornadas Aragonesas de Paleontología: " La expansión de la vida en el Cámbrico". Libro homenaje al Prof. Klaus Sdzuy (Eds. J.A. Gámez Vintaned y E. Liñán). Institución Fernando el Católico, Zaragoza, 253-263.

Sdzuy, K. y Liñán, E. 1993. Rasgos paleográficos del Cámbrico Inferior y Medio del Norte de España. Cuadernos do Laboratorio Xeolóxico de Laxe, 18, 189215.
Sdzuy, K. and Liñán, E. 1997. Cornucoryphe schirmi n. g., n. sp., an unusual conocoryphid trilobite from the Middle Cambrian of Spain. Paläontologische Zeitschrift, 70, 433-438.

Shergold, J. H. and Sdzuy, K. 1991. Late Cambrian trilobites from the Iberian Mountains, Zaragoza Province, Spain. Beringeria, 4, 193-235.

Streng, M. 1997. Early Middle Cambrian representatives of the superfamily Acrotretoidea (Brachiopoda) from Morocco. Diploma dissertation, 1-71. Würzburg. (Unpublished).

Termier, G. et Termier, H. 1974. Les Brachiopodes cambriens de la Montagne Noire (Sud de la France). Géologie Méditerranéenne, 1 (2), 35-52.

Valenzuela, J. I., Gámez, J. A, Liñán, E. y Sdzuy, K. 1990. Estratigrafía de la región de Brea. Cadena Ibérica Oriental. Boletín de la Real Sociedad Española de Historia Natural (Sección Geológica), 85, 45-54.

Verneuil, E. P. de et Barrande, J. 1860. Descriptions des fossiles. Sur l'existence de la faune primordiale dans la chaine Cantabrique. Bulletin de la Société géologique de France, $2 d$ ser. 17, 526-542.

Vogel, K. 1962. Muscheln mit Schlosszähnen aus dem spanischen Kambrium und ihre Bedeutung für die Evolution der Lamellibranchiaten. Abhandlungen der Mathematische. Naturwissenschaftlichen Klasse, 4, 193244.

Walcott, C.D. 1905. Cambrian Brachiopoda with descriptions of new genera and species. Proceedings of the United States National Museum, 28, 227-337.

Walcott, C. D. 1908. Cambrian Geology and Palaeontology. 3. Cambrian Brachiopoda, descriptions of new genera and species: 4. Classification and terminology of the Cambrian brachiopoda: Smithsonian Miscellaneous Collections, 53, 53-165.

Walcott C. D. 1912. Cambrian Brachiopoda. U. S. Geological Survey Monograph, 51, 1-872.

White, C.A. 1874. Preliminary report upon invertebrate fossils collected by the expeditions of 1871, 1872 and 1873 with description from species. United States Geographical Surveys west of the $100^{\text {th }}$ Meridian, 1874, 5-27.

Zell M. G. and Rowell A. J. 1988. Brachiopods of the Holm Dal Formation (late Middle Cambrian), central North Greeland. Meddelelser om Gronland, Geoscience, 20, 119-144. 